*ak RMIS View/Frint Document Cover Sheet tow

This document was retrieved from the Documentation and Records Manaqement (DRM) ISEARCH System. It is intended for Information only and may not be the most recent or updated version. Contact a Document Service Center (see Hanford Info for locations) if you need additional retrieval information.

Accession \#: D196029172

Document \#: SD-EN-TP-055

Title/Desc:

IN SITU GAS TREATMENT TECHNOLOGY DEMONSTRATION TEST PLAN

Pages: 48 


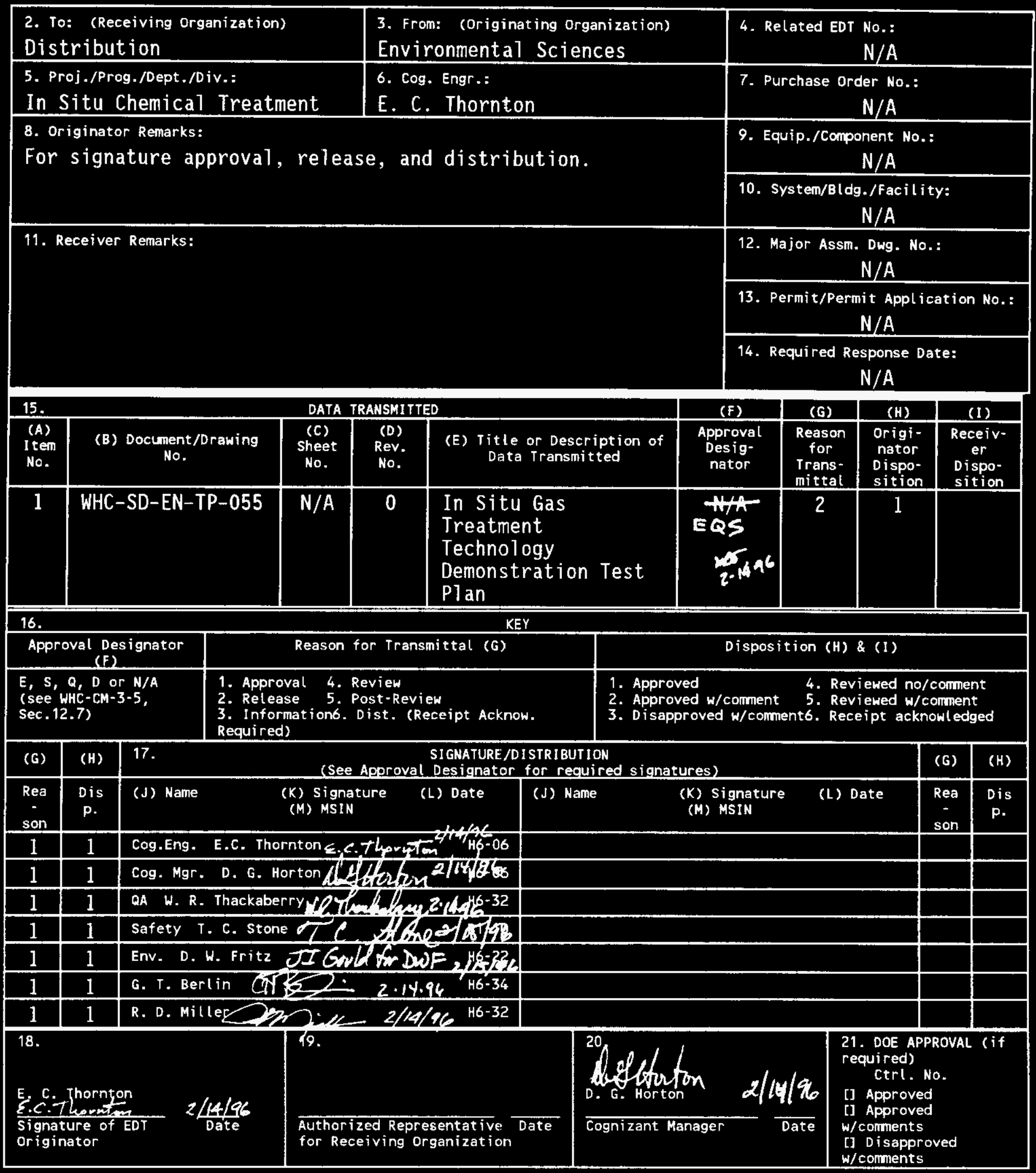




\section{In Situ Gas Treatment Technology Demonstration Test Plan}

E. C. Thornton

R. D. Miller

Westinghouse Hanford Company, Richland, WA 99352

U.S. Department of Energy Contract DE-AC06-87RL10930

$\begin{array}{ll}\text { EDT/ECN: } 614669 & \text { UC: } 2010 \\ \text { Org Code: } 8 \text { H220 } & \text { Charge Code: H1DAA } \\ \text { B\&R Code: } 35 \text { EW40100 } & \text { Total Pages: } 43\end{array}$

Key Words:

hexavalent chromium, field demonstration, in situ chemical treatment

Abstract:

This document defines the objectives and requirements associated with undertaking a field demonstration of an in situ gas treatment appoach to remediating chromate-contaminated soil. The major tasks presented in this plan include the design and development of the surface gas treatment system, performance of permitting activities, and completion of site preparation and field testing activities.

TRADEMARK DISCLAIMER. Reference herein to any specific commercial product, process, or service by trade name, trademark, manufacturer, or otherwise, does not necessarily constitute or imply its endorsement, recommendation, or favoring by the United States Governmient or any agency thereof or its contractors or subcontractors.

Printed in the United States of America. To obtain copies of this document, contact: WHC/BCS Document Control Services, P.O. Box 1970, Mailstop H6-08, Richland WA 99352, Phone (509) 372-2420; Fax (509) 376-4989.
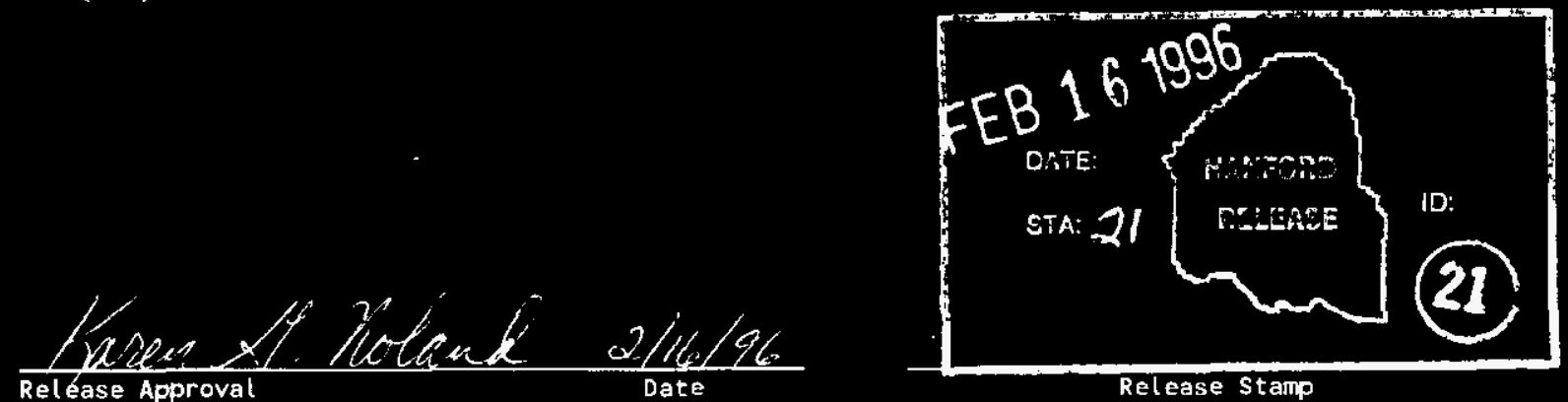

Release Stamp

\section{Approved for Public Release}




\section{ABSTRACT}

Laboratory bench-scale testing activities indicate that in situ treatment of chromate-contaminated soils through the injection of diluted hydrogen sulfide gas mixtures may be a feasible and effective remediation approach. This document defines the objectives and requirements associated with undertaking a field demonstration of this technology. The proposed tests will be performed at a waste site located at the DOD White Sands Missle Range.

The major tasks presented in this plan include the design and development of the surface gas treatment system, performance of permitting activities, and completion of site preparation and field testing and demonstration activities. These activities will be conducted in conformance with procedures and requirements defined by the environmental restoration program manager at the White Sands Missle Range, and other applicable federal and state requirements. The Westinghouse Hanford Company will have responsibility for conducting laboratory treatability studies, developing the gas treatment system, and operating the system during the demonstration. Project staff associated with Sandia National Laboratories have responsibility for demonstration coordination and permitting activities, site characterization activities, installation of the injection/extraction wellfield network, and completion of post-test site restoration activities. Post-demonstration characterization activities in support of cost and performance analyses of this technology will also be performed.

A schedule and major milestones for the demonstration are presented for planning purposes. 
WHC-SD-EN-TP-055, Rev. 0

\section{ACKNOWLEDGMENTS}

This work is funded by the Office of Science and Technology (EM-50), within the U.S. Department of Energy's Office of Environmental Management, under the Plumes Focus Area Metals and Radionuclides Product Line. 
WHC-SD-EN-TP-055, Rev. 0

CONTENTS

1.0 INTRODUCTION. . . . . . . . . . . . . . . . . 1

1.1 PURPOSE AND SCOPE. . . . . . . . . . . . . . . . 1

1.2 BACKGROUND . . . . . . . . . . . . . . . . . . . . . 2

1.3 SITE DESCRIPTION . . . . . . . . . . . . 2

2.0 TECHNOLOGY DESCRIPTION . . . . . . . . . . . . . 6

2.1 SURFACE GAS TREATMENT AND CONTROL SYSTEM . . . . . . . 6

2.2 WELLFIELD NETWORK DESIGN AND SUBSURFACE CONTROL SYSTEM . . . . 9

2.3 INSTALLATION AND OPERATION ............. 12

2.4 SAFETY AND PERFORMANCE MONITORING OF FIELD DEMONSTRATION . . . 13

3.0 DATA QUALITY OBJECTIVES AND PERFORMANCE EVALUATION . . . . . . 14

3.1 SPECIFIC DEMONSTRATION OBJECTIVES . . . . . . . . . . 14

3.2 SOIL SAMPLING AND CHARACTERIZATION REQUIREMENTS $\ldots \ldots . . . . \quad 16$

3.3 GAS ANALYSIS REQUIREMENTS . . . . . . . . . . . . . 17

3.4 TREATABILITY TESTING REQUIREMENTS . . . . . . . . . . . . . . 19

3.5 OPERATING PARAMETERS AND PERFORMANCE EVALUATION . . . . . . 20

3.5.1 Expected Results . . . . . . . . . . . . 20

3.5.2 Surface Treatment System Performance . . . . . . 20

3.5.3 Gas Flow Characteristics of the

Wellfield Network .............. 20

3.5.4 Gas Treatment Parameters for Chromate-Contaminated Soils . 21

3.5.5 Preliminary Cost Analys is . . . . . . . . . 23

4.0 REgULATORY COMPLIANCE . . . . . . . . . . . . . . . 26

4.1 NATIONAL ENVIRONMENTAL POLICY ACT . . . . . . . . . 26

4.2 RESOURCE CONSERVATION AND RECOVERY ACT . . . . . . . . 27

4.3 CLEAN AIR ACT . . . . . . . . . . . . . . . . . . . 27

4.4 EMERGENCY PLANNING AND COMMUNITY RIGHT-TO-KNOW ACT $\ldots . . . \quad . \quad 27$

5.0 SITE COMPLIANCE . . . . . . . . . . . . . . 28

5.1 SAFETY . . . . . . . . . . . . . . . . . . . 28

5.2 TRAINING . . . . . . . . . . . . . . . . 29

5.3 WASTE GENERATION AND MANAGEMENT . . . . . . . . . . 29

5.4 SITE CLOSURE . . . . . . . . . . . . . . . . 29

6.0 DESCRIPTION OF PROJECT TASKS . . . . . . . . . . . . . . . . 30

6.1 WORK ELEMENT A: PROJECT MANAGEMENT . . . . . . . . 30

6.2 WORK ELEMENT B: GAS TREATMENT SYSTEM DESIGN AND FABRICATION * 30

6.3 WORK ELEMENT C: PERMIT APPLICATIONS AND REGULATORY COMPLIANCE * 31

6.4 WORK ELEMENT D: SITE PREPARATION AND FIELD DEMONSTRATION . . . 31

7.0 ORGANIZATION AND PERSONNEL RESPONSIBILITIES . . . . . . . . 32

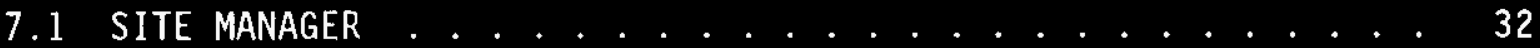

7.2 PRINCIPAL INVESTIGATOR . . . . . . . . . . . . . . . 33

7.3 TECHNOLOGY DEMONSTRATION COORDINATOR . . . . . . . . . . 33

8.0 SITE SERVICES REQUIREMENTS ............... 33 
9.0 DEMONSTRATION SCHEDULE . . . . . . . . . . . . 34

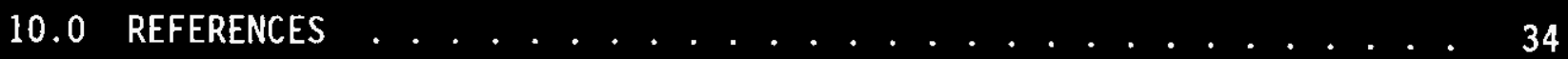

\section{LIST OF FIGURES}

1. Location of the Chromate Spill waste Site.......... 3

2. Approximate Locations of RFI Phase-I and Phase-II Soil Boreholes . . 5

3. Schematic Diagram of the Gas Treatment System . . . . . . . . 7

4. Perspective View of the Gas Treatment System . . . . . . . . 8

5. Configuration of Gas Injection and Extraction We11s and Soil Sampling Locations................ 10

6. Cross Section of the Wellfield Network . . . . . . . . . . . 11

7. Injection Zone Head Contours with Particle Tracks Overlaid . . . . 22

8. Hydrogen Sulfide Concentration versus Treatment Time at Various Gas flow Rates . . . . . . . . . . . . . 24

\section{LIST OF TABLES}

1. Chromium Analytical Methods, Analytes of Interest, Quantitation Limits, and Precision and Accuracy Guidelines ........ 18

2. Summary of Estimated Technology Costs . . . . . . . . . 25 
WHC-SD-EN-TP-055, Rev. 0

\section{ACRONYMS}

$\begin{array}{ll}\text { bgs } & \text { below ground surface } \\ \text { cfm } & \text { cubic feet per minute } \\ \text { DOD } & \text { U.S. Department of Defense } \\ \text { DOE } & \text { U.S. Department of Energy } \\ \text { DOT } & \text { U.S. Department of Transportation } \\ \text { EPA } & \text { U.S. Environmental Protection Agency } \\ \text { H S } & \text { hydrogen sulfide } \\ \text { HELSTF } & \text { High Energy Laser System Test Facility } \\ \text { HSWA } & \text { Hazardous and Sol id Waste Amendments of 1984 } \\ \text { MSDS } & \text { Material Safety Data Sheet } \\ \text { NEPA } & \text { National Environmental Pol icy Act } \\ \text { OSHA } & \text { U.S. Occupational Safety and Health Administration } \\ \text { PFA } & \text { Plume Focus Area } \\ \text { PI } & \text { Principal Investigator } \\ \text { RCRA } & \text { Resource Conservation and Recovery Act of 1976 } \\ \text { RFI } & \text { RCRA Facility Investigation } \\ \text { SNL } & \text { Sandia National Laboratories } \\ \text { SWMU } & \text { Solid waste management unit } \\ \text { TCLP } & \text { Toxic Characteristic Leach Procedure } \\ \text { TOC } & \text { Technology Demonstration Coordinator } \\ \text { USGS } & \text { U.S. Geological Survey } \\ \text { VOC } & \text { volatile organic compound } \\ \text { WHC } & \text { Westinghouse Hanford Company } \\ \text { WSMR } & \text { White Sands Missle Range }\end{array}$




\section{METRIC CONVERSION CHART}

The following conversion chart is provided to aid in conversion.

Into metric units

Out of metric units

\begin{tabular}{|c|c|c|c|c|c|}
\hline If you know & $\begin{array}{c}\text { Multiply } \\
\text { by }\end{array}$ & To get & If you know & $\begin{array}{c}\text { Multiply } \\
\text { by }\end{array}$ & To get \\
\hline \multicolumn{3}{|c|}{ Length } & \multicolumn{3}{|c|}{ Length } \\
\hline inches & 25.40 & millimeters & millimeters & 0.0393 & inches \\
\hline inches & 2.54 & centimeters & centimeters & 0.393 & inches \\
\hline feet & 0.3048 & meters & meters & 3.2808 & feet \\
\hline yards & 0.914 & meters & meters & 1.09 & yards \\
\hline miles & 1.609 & kilometers & kilometers & 0.62 & miles \\
\hline \multicolumn{3}{|c|}{ Area } & \multicolumn{3}{|c|}{ Area } \\
\hline $\begin{array}{l}\text { square } \\
\text { inches }\end{array}$ & 6.4516 & $\begin{array}{l}\text { square } \\
\text { centimeters }\end{array}$ & $\begin{array}{l}\text { square } \\
\text { centimeters }\end{array}$ & 0.155 & $\begin{array}{l}\text { square } \\
\text { inches }\end{array}$ \\
\hline square feet & 0.092 & $\begin{array}{l}\text { square } \\
\text { meters }\end{array}$ & $\begin{array}{l}\text { square } \\
\text { meters }\end{array}$ & 10.7639 & $\begin{array}{l}\text { square } \\
\text { feet }\end{array}$ \\
\hline $\begin{array}{l}\text { square } \\
\text { yards }\end{array}$ & 0.836 & $\begin{array}{l}\text { square } \\
\text { meters }\end{array}$ & $\begin{array}{l}\text { square } \\
\text { meters }\end{array}$ & 1.20 & $\begin{array}{l}\text { square } \\
\text { yards }\end{array}$ \\
\hline $\begin{array}{l}\text { square } \\
\text { miles }\end{array}$ & 2.59 & $\begin{array}{l}\text { square } \\
\text { kilometers }\end{array}$ & $\begin{array}{l}\text { square } \\
\text { kilometers }\end{array}$ & 0.39 & $\begin{array}{l}\text { square } \\
\text { miles }\end{array}$ \\
\hline acres & 0.404 & hectares & hectares & 2.471 & acres \\
\hline & Mass (weight & & \multicolumn{3}{|c|}{ Wass (weight) } \\
\hline ounces & 28.35 & grams & grams & 0.0352 & ounces \\
\hline pounds & 0.453 & kilograms & kilograms & 2.2046 & pounds \\
\hline short ton & 0.907 & metric ton & metric ton & 1.10 & short ton \\
\hline \multicolumn{3}{|c|}{ Volume } & \multicolumn{3}{|c|}{ Volume } \\
\hline $\begin{array}{l}\text { fluid } \\
\text { ounces }\end{array}$ & 29.57 & milliliters & mil1i1iters & 0.034 & $\begin{array}{l}\text { fluid } \\
\text { ounces }\end{array}$ \\
\hline quarts & 0.95 & 1iters & liters & 1.057 & quarts \\
\hline gallons & 3.79 & Titers & liters & 0.26 & gallons \\
\hline cubic feet & 0.028 & $\begin{array}{l}\text { cubic } \\
\text { meters }\end{array}$ & $\begin{array}{l}\text { cubic } \\
\text { meters }\end{array}$ & 35.3147 & cubic feet \\
\hline cubic yards & 0.76 & $\begin{array}{l}\text { cubic } \\
\text { meters }\end{array}$ & $\begin{array}{l}\text { cubic } \\
\text { meters }\end{array}$ & 1.308 & $\begin{array}{l}\text { cubic } \\
\text { yards }\end{array}$ \\
\hline \multicolumn{3}{|c|}{ Temperature } & \multicolumn{3}{|c|}{ Temperature } \\
\hline Fahrenhe it & $\begin{array}{l}\text { subtract } \\
32 \text { then } \\
\text { multiply } \\
\text { by } 5 / 9 \text { ths }\end{array}$ & Celsius & Celsius & $\begin{array}{l}\text { multiply } \\
\text { by } \\
9 / 5 \text { ths, } \\
\text { then add } \\
32\end{array}$ & Fahrenheit \\
\hline
\end{tabular}

Source: Engineering Unit Conversions, M. R. Lindeburg, PE., Second Ed., 1990, Professional Publications, Inc., Belmont, California. 
WHC-SD-EN-TP-055, Rev. 0

\subsection{INTRODUCTION}

This technology demonstration test plan has been prepared to define the objectives and requirements associated with undertaking a demonstration of an in situ approach to soil treatment through the use of reactive gas mixtures. The field tests associated with this demonstration will be conducted at a chromate-contaminated soil waste site in the High Energy Laser System Test Facility (HELSTF) area within the DOD White Sands Missle Range (WSMR), southcentral New Mexico.

The gas injection and recovery systems discussed in this document have been designed to perform gaseous treatment in unsaturated soils in an

environmentally safe manner by controlling the amount and rate of gas addition to the site and subsequent extraction of treatment gas residuals from the soil. This technology has potential applications for immobilizing a number of inorganic constituents (e.g, uranium, chromium, lead, and cadmium). The data collected during and subsequent to the demonstration will be used to evaluate the technical performance of the in situ gas treatment approach for reducing and immobilizing hexavalent chromium. The data will also be used to obtain cost estimates of performing gaseous reduction remediation in unsaturated soils.

Responsibilites for activities associated with this demonstration will be shared by staff associated with the Westinghouse Hanford Company (WHC) and Sandia National Laboratories (SNL). WHC is primarily responsible for development of the technology and for operation of the gas treatment system during the demonstration. SNL is responsible for coordinating the demonstration and preparing permitting documentation, and for conducting field characterization activities, installing the wellfield network, and completing post-test site restoration activities. All activities will be performed in conformance with regulatory and site-specific requirements, as defined by the environmental restoration program manager for WSMR. A phased approach with decision points will be followed during the demonstration to ensure a high level of safety in operations.

\subsection{PURPOSE AND SCOPE}

The primary role of this plan is to define technical, regulatory, and monitoring requirements associated with the demonstration and to support the planning and execution of field activities. Revisions of this document will be issued, as necessary, during the course of the project as more site specific and operational information becomes available.

Technical descriptions of the surface and subsurface systems related to the demonstration, and procedures and requirements associated with their installation and operation are presented in Section 2.0 of this document. Data quality objectives, performance goals, anticipated treatment costs, and designation of sampling and analytical requirements are provided in Section 3.0. Sections 4.0 and 5.0 discuss regulatory and site compliance requirements relevant to conducting the demonstration. Organizational responsibilities and identification of key personnel and their

responsibilities are presented in Section 6.0. Descriptions of the major 
WHC-SD-EN-TP-055, Rev. 0

tasks associated with the demonstration are provided in Section 7.0 and related schedules are presented in Section 9.0. Specific onsite service requirements are identified in Section 8.0 .

\subsection{BACKGROUND}

In situ treatment approaches, such as that proposed here, have a number of potential benefits to waste site remediation. Remediation of soil by in situ gaseous treatment will reduce exposure of workers to contaminated media compared to conventional technologies such as excavation. It will also minimize secondary waste generation. Cost savings may be significant since the construction of surface treatment and disposal facilities will be minimized. Treatment of soils with gaseous agents also has the specific advantages of ease of control and removal of the treatment agent with virtually no disturbance to the site.

In situ gas treatment has significant potential for application, in particular, to the remediation of soils contaminated with hexavalent chromium. However, other metals and radionuclides such as lead, cadmium, and uranium may also be immobilized by this approach. Laboratory testing activities to develop this technology are currently being conducted by the Westinghouse Hanford Company (WHC) to develop this technology under support provided by the D0E Plumes Focus Area Metals and Radionuclides Product Line program. Results of this work indicate, in particular, that a $100 \mathrm{ppm}$ mixture of hydrogen sulfide in nitrogen can immobilize $>90 \%$ of $\mathrm{Cr}$ (VI) present in contaminated soils (Thornton et al. 1994). Byproducts of this treatment approach to chromate contaminated soils are nontoxic constituents commonly present in natural soil environments.

A field test will be performed at the waste site with the goal of treating chromium-contaminated soils in situ with hydrogen sulfide $\left(\mathrm{H}_{2} \mathrm{~S}\right)$ gas mixtures diluted in air. Hydrogen sulfide has the capability of reducing chromium from the hexavalent to the trivalent oxidation state, thereby lowering the toxicity and mobility of chromium. Implementation of this approach is similar to that employed in vacuum extraction technologies, which have proven to be effective and economical in remediation of soils contaminated with organic chemicals (Pederson and Curtis 1991).

\subsection{SITE DESCRIPTION}

A demonstration of the in situ gas treatment approach is proposed to be undertaken at SWMU 143, which is located at the east corner of the HELSTF Equipment Storage Area (Figure 1). This waste site resulted from an accidental spill of a drum of Entec 300, a hexavalent chromium based corrosion inhibitor. An estimated $200 \mathrm{~L}(55 \mathrm{gal})$ of the material was released to the soil as a result of drum mishandling operations. Informal investigation has indicated that the release probably occurred in 1982 or 1983.

The spill site was discovered in January 1990 when preparations were underway to pave the site. Approximately 17 drums of contaminated soil were subsequently removed from the spill site. The site was then enfilled with 
WHC-SD-EN-TP-055, Rev. 0

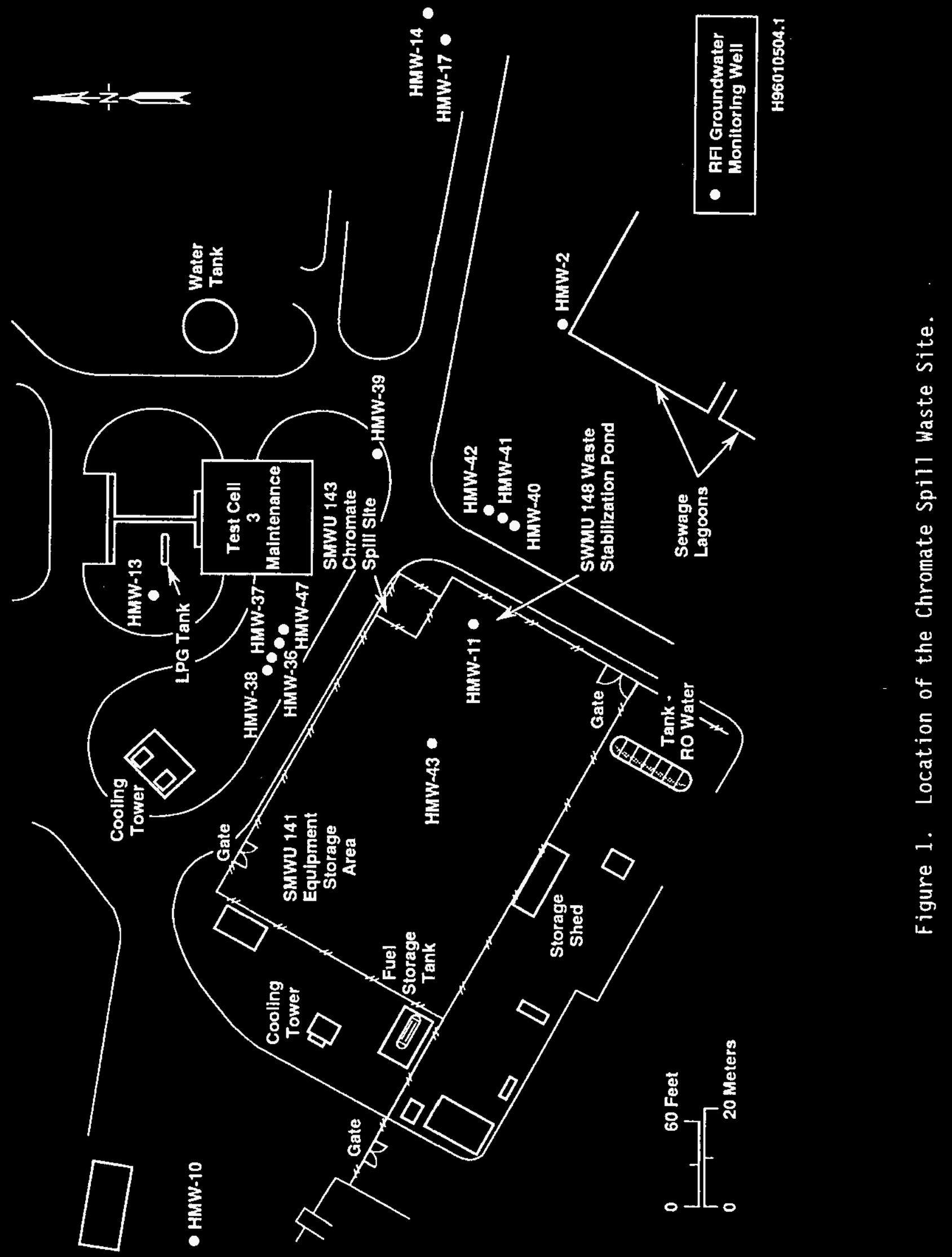


WHC-SD-EN-TP-055, Rev. 0

about $2.4 \mathrm{~m}(8 \mathrm{ft})$ of clean $\mathrm{fj} 11$ and covered with a shingled wooden roof structure to inhibit leaching and runoff. A 9-m $(30-\mathrm{ft})$ square fence has been placed around the site. No data has been located concerning the levels of chromium present in the soil removed during excavation of the site.

Shallow borings were later drilled at SMWU 143 during a Phase-I RCRA Facility Investigation (RFI) conducted in 1992. Results of metal analyses for eight soil samples collected from three soil borings (ranging in depth from 3.1 to $9.1 \mathrm{~m}$ [10 to $30 \mathrm{ft}]$ ) situated in the spill area (Figure 2) indicated total chromium concentrations up to $14 \mathrm{mg} / \mathrm{kg}$ (sample collected at $3.1 \mathrm{~m}$ (10 ft) depth in Phase-I soil borehole \#3). The background total chromium level for the area is $0.031 \mathrm{mg} / \mathrm{kg}$. A11 other metal concentrations were near background levels. Green-tinted soil was also reportedly observed at the site, suggesting that some residual contamination is present.

An additional six $3.1-\mathrm{m}(10-\mathrm{ft})$ soil borings were subsequently completed during a Phase-II RFI conducted in 1993 (Figure 2), and soil samples collected at depths of $0,1.2$, and $2.7 \mathrm{~m}(0,4$, and $9 \mathrm{ft})$ were analyzed for chromium. Neither total nor hexavalent chromium were detected above their quantitation limits (approximately $6 \mathrm{mg} / \mathrm{kg}$ ). Consideration of the location and depth of these boreholes, however, suggests that they were possibly situated outside the zone of contamination.

Chromate contamination at the site is further indicated by local groundwater monitoring activities. A water sample collected during Phase-I from groundwater monitoring well HMW-11 (Figure 1) contained hexavalent chromium, total chromium, 1,1-dichloroethylene, and trichlorethylene levels exceeding Federal and State MCLs and State groundwater protection standards. The water reportedly had a strong greenish-yellow tint. It is believed that the chlorinated solvents did not originate in SWMU 143. A total of fifteen groundwater samples were collected during Phase-II. The monitoring wells with the most substantial concentrations of hexavalent chromium were HMW-11, HMW-39, and HMW-41 with levels of 2710,1380 , and $10,500 \mu \mathrm{g} / 1$, respectively.

The shallow stratigraphy beneath SWMU 143 can be characterized on the basis of down-hole geophysical logs and 1ithologic descriptions associated with the installation of Phase-I and Phase-II monitoring wells (primarily HMW-11). From the surface to a depth of about $6 \mathrm{~m}(20 \mathrm{ft})$ bgs, a sequence of gypsiferous sand, silt, and clay is present. Below this is detrital sand, silt, and clay.

The groundwater table at SWMU 143 is located at approximately $13 \mathrm{~m}(40 \mathrm{ft})$ bgs. This is inferred to be a perched water bearing zone overlying the regional aquifer. The local discontinous stratigraphy of the shallow water bearing zone in the area makes interpretation of the hydrogeology difficult.

The grain size distribution of transmissive zones within the screened zones of Phase-II wells indicate that these intervals are mainly silty sand with some clay. Hydraulic conductivities, estimated form slug test data obtained during Phase-I and Phase-II, ranged from $8.49 \times 10^{-6} \mathrm{~cm} / \mathrm{sec}(0.02 \mathrm{ft} /$ day $)$ in $\mathrm{HMW}-40$ to $2.15 \times 10^{-3} \mathrm{~cm} / \mathrm{sec}(6.08 \mathrm{ft} / \mathrm{day})$ in $\mathrm{HMW}-37$. 
WHC-SD-EN-TP-055, Rev. 0

Figure 2. Approximate Locations of RFI Phase-I and Phase-II Soil Boreholes.

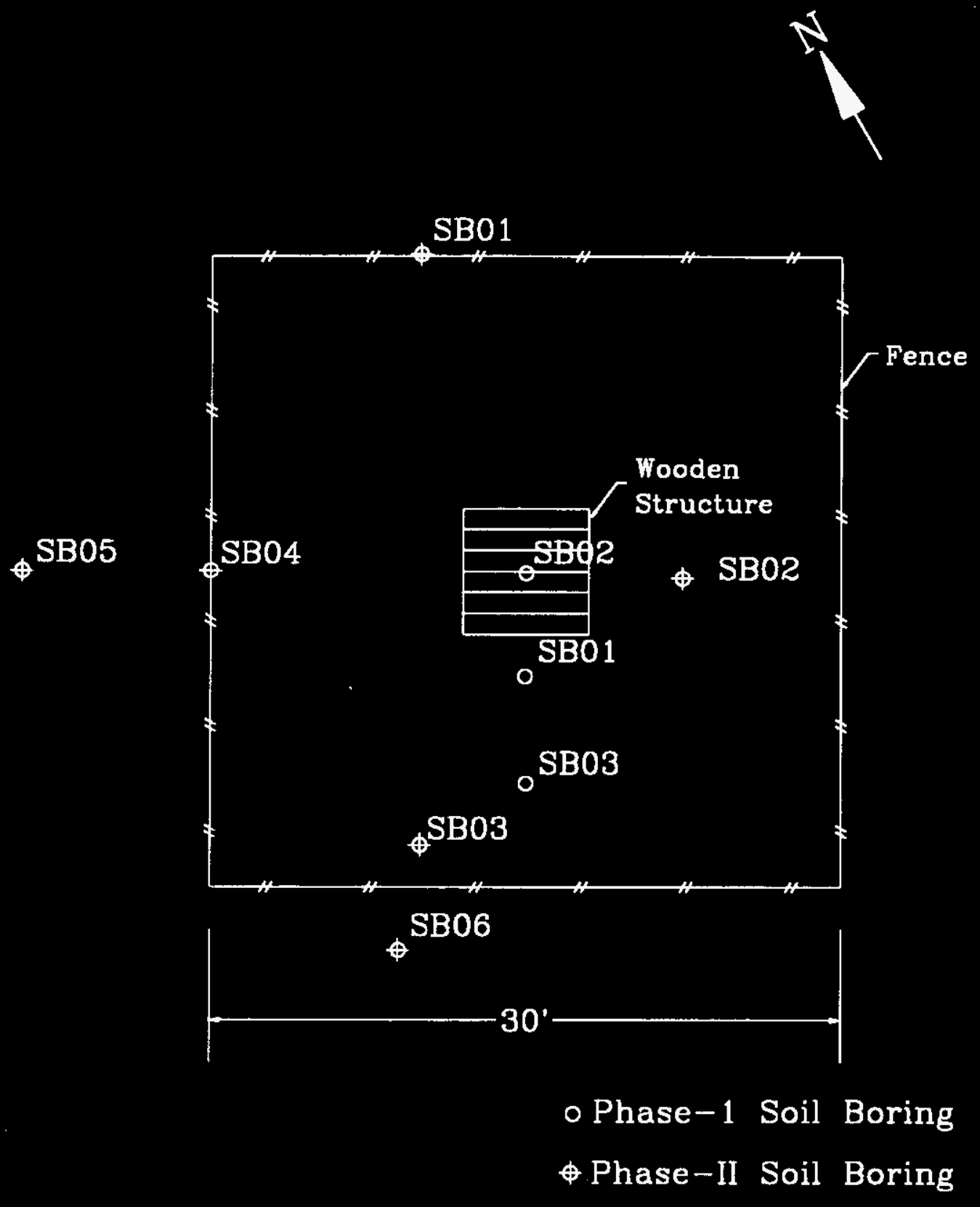


WHC-SD-EN-TP-055, Rev. 0

\subsection{TECHNOLOGY DESCRIPTION}

Various inorganic contaminant constituents can be immobilized through the precipitation of solid compounds produced by interaction with gaseous treatment agents. Chemical reduction of $\mathrm{Cr}(\mathrm{VI})$, or hexavalent chromium, to $\mathrm{Cr}$ (III), or trivalent chromium, serves to detoxify as well as immobilize chromium. The application of gaseous reduction to unsaturated soils has been discussed by Thornton and Trader (1993), Thornton and Jackson (1994), and Thornton et al. (1994). Laboratory testing activities have demonstrated that $>90 \%$ immobilization of hexavalent chromium can be achieved by treatment of contaminated soils with highly diluted hydrogen sulfide gas mixtures.

The chemical reaction associated with the treatment of hexavalent chromium may be summarized as follows:

$$
8 \mathrm{CrO}_{4}^{2-}+3 \mathrm{H}_{2} \mathrm{~S}+10 \mathrm{H}^{+}+4 \mathrm{H}_{2} \mathrm{O} \rightarrow 8 \mathrm{Cr}(\mathrm{OH})_{3}+3 \mathrm{SO}_{4}^{2-}
$$

Note that hydrogen sulfide is converted to sulfate in this reaction and that 3 moles of hydrogen sulfide are required to reduce 8 moles of $\mathrm{Cr}$ (VI) to $\mathrm{Cr}$ (III). Since sulfate is not generally regarded as a contaminant of concern and chromium (III) hydroxide is an insoluble and essentially nontoxic solid, it is unlikely that a significant quantity of hazardous byproducts will be generated by the gas treatment approach. Excess hydrogen sulfide can be removed from the soil by purging with air after treatment has been completed.

In the demonstration, gas remediation will be undertaken by injecting a diluted mixture of hydrogen sulfide into a field soil site contaminated with hexavalent chromium. The major systems associated with the demonstration are the surface system for makeup of the treatment gas and the associated pumps for injection and withdrawal, and the wellfield network consisting of the injection and extraction wells. The technical activities associated with the design and development of these two systems are described below.

\subsection{SURFACE GAS TREATMENT AND CONTROL SYSTEM}

A prototype gas treatment system has been designed and fabricated by WHC. The system is equipped with an injection pump, extraction pump, water knockout tank, and a scrubber (Figures 3 and 4 ). The injection pump is a Model DR 823, EG\&G Rotron Regenerative Blower that will inject an air stream containing 100-500 ppm hydrogen sulfide at maximum rate of $5.2 \mathrm{~m}^{3} / \mathrm{min}\left(184 \mathrm{ft}^{3} / \mathrm{min}\right)$ into the soil. The extraction pump is a Model DR 808, EG\&G Rotron Regenerative Blower, and will extract air and un-reacted hydrogen sulfide at a maximum rate of $9.8 \mathrm{~m}^{3} / \mathrm{min}\left(345 \mathrm{ft}^{3} / \mathrm{min}\right)$ from the soil through a water knock-out tank, and then pass it through a scrubber. A granular activated carbon (GAC) canister can be added to the system if VOCS are present in the extracted gas stream.

The water knock-out tank is located on the vacuum side of the extraction pump and serves to remove debris and moisture from the air. The scrubber is positioned on the positive pressure side of the extraction pump; its function is to remove the un-reacted hydrogen sulfide gas from the air stream prior to discharge. The scrubbing fluid consists of $57 \mathrm{~L}$ (15 gal) of a caustic 
WHC-SD-EN-TP-055, Rev. 0

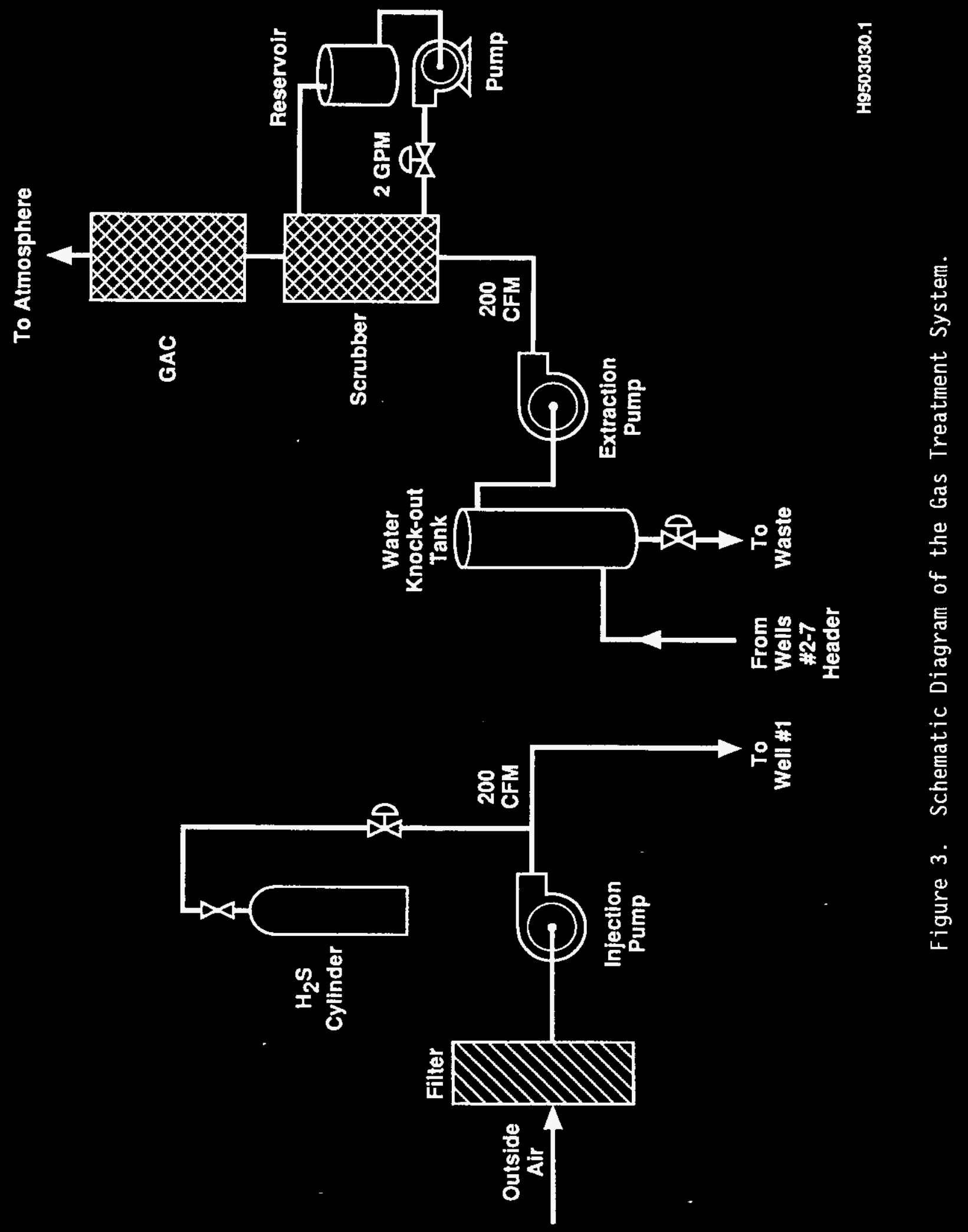


WHC-SD-EN-TP-055, Rev. 0

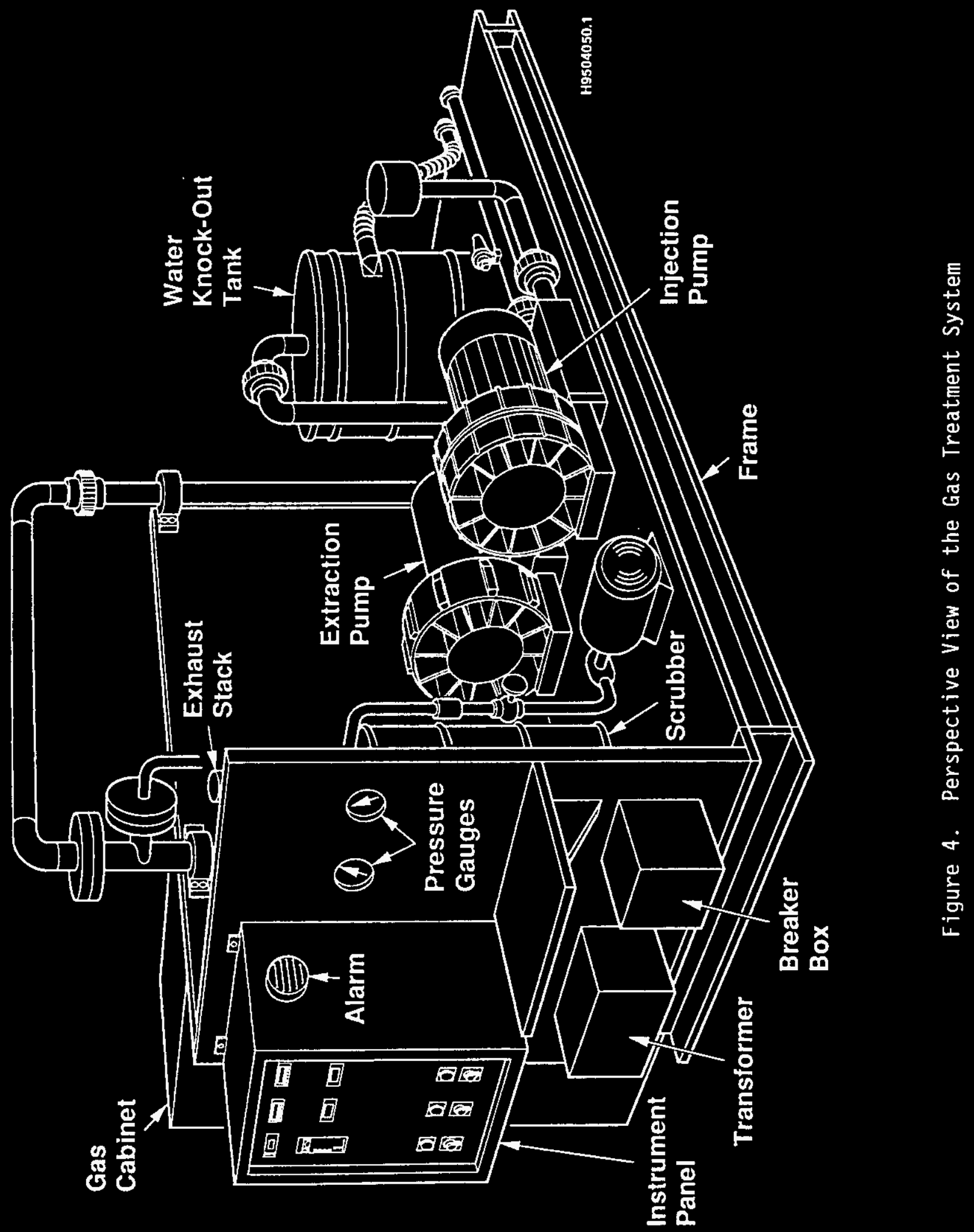


WHC-SD-EN-TP-055, Rev. 0

solution (e.g., one molar $\mathrm{NaOH}$ ) recirculated through the scrubber at a rate of approximately $7.6 \mathrm{~L} / \mathrm{min}(2 \mathrm{gal} / \mathrm{min}$ ). Measurement of $\mathrm{pH}$ serves to ensure efficient removal of hydrogen sulfide before discharge. The scrubber exhaust stack is also equipped with a hydrogen sulfide sensor to monitor the discharged gas stream.

The gas treatment system operates on 480 volt, 60 amp line power. A portable generator can be added in the field if line power is not available or to provide backup power in the event of a site power failure. The hydrogen sulfide cylinders will also be equipped with automatic shutoff valves to prevent release of treatment gas if a power failure occurs.

WHC has prepared an acceptance test plan (ATP) to verify that the prototype operates as designed (Larkin 1995). The preliminary tests outlined in the ATP have been satisfactorily completed. The following interlocks/safety systems have been configured into the system and were checked during the acceptance test and determined to be functional:

- The injection pump will not operate without the extraction pump a]ready in operation.

- A high level switch within the water knock-out tank, when activated, will shut down the extraction pump, the injection pump, and stop the flow of injection gas.

- A hydrogen sulfide monitor high level alarm will shut down the injection pump, extraction pump, stop the flow of injection gas, and sound an alarm.

The gas system will undergo more extensive operational testing activities in early FY 1996 and operational procedures will be developed. An electronic datalogging system is also being developed to permit continuous acquisition and storage of system performance data generated during the demonstration.

\subsection{WELLFIELD NETWORK DESIGN AND SUBSURFACE CONTROL SYSTEM}

In applying the gas treatment approach to the remediation of the chromatecontaminated soil site, hydrogen sulfide will be mixed with air to a specified concentration and then introduced to the soil by pressure injection through a central borehole (Figures 5 and 6). The dilute gas mixture will then be drawn through the contaminated soil mass by vacuum applied to a network of six extraction wells located at the edge of the waste site. The extraction wells will be placed in a hexagonal configuration with a network diameter of $9.2 \mathrm{~m}$ $(30 \mathrm{ft})$ and screened in the 7.6 to $10.7 \mathrm{~m}(25$ to $35 \mathrm{ft})$ interval.

The site will be capped with an impermeable cover during the demonstration to minimize escape of the treatment gas. The cover should be a good quality composite geomembrane/geosynthetic clay liner that is resistant to acidic corrosion. A vent will be placed in the cover to permit removal of any gases collecting under it. A hydrogen sulfide electrochemical sensor will be placed in the vent or beneath the cover to monitor the accumulation of gas by the cover. 
WHC-SD-EN-TP-055, Rev. 0

Figure 5. Configuration of the Gas Injection and Extraction Wells and Soil Sampling Locations.

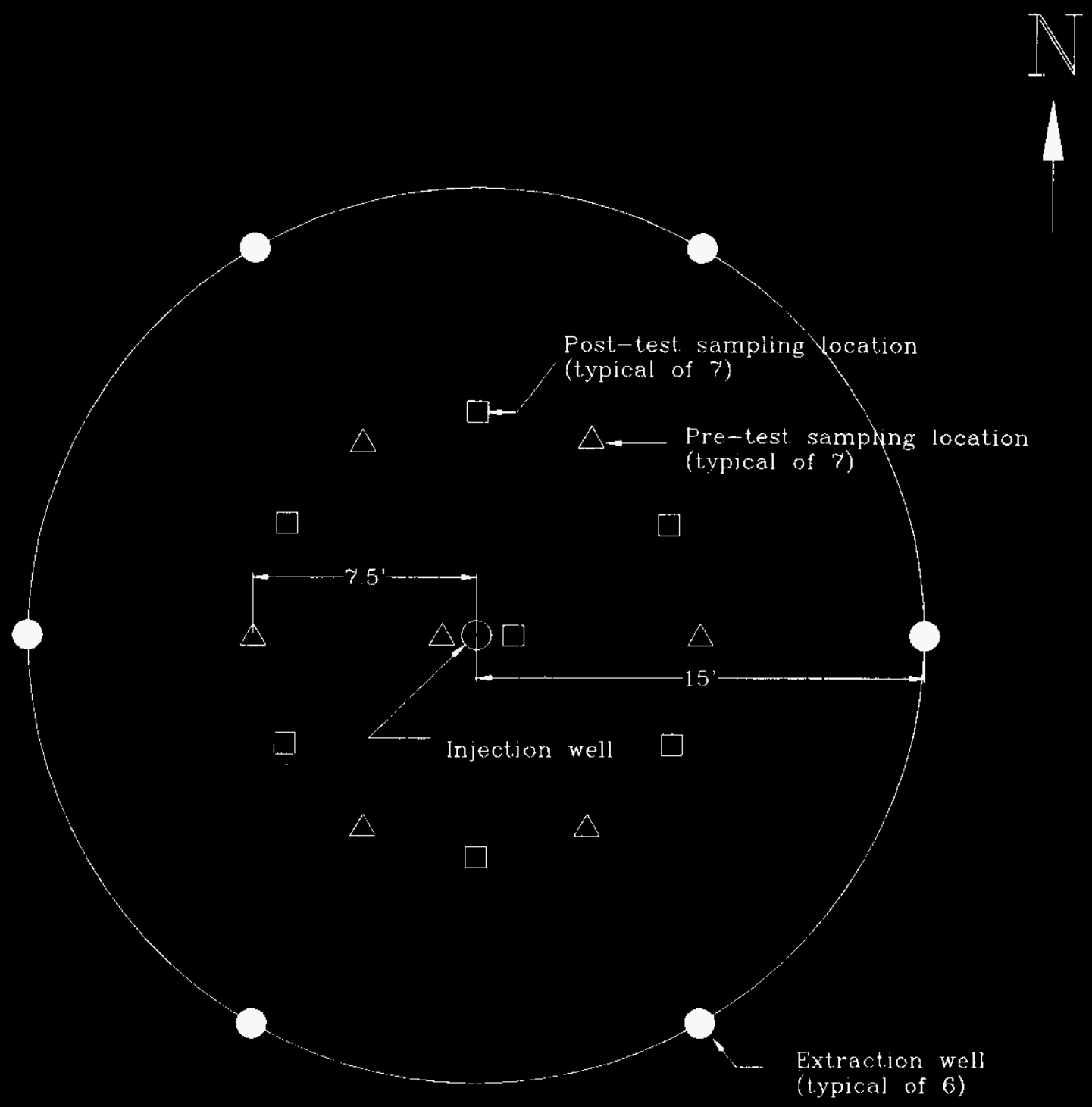


WHC-SD-EN-TP-055, Rev. 0

Figure 6. Cross Section of the Wellfield Network.

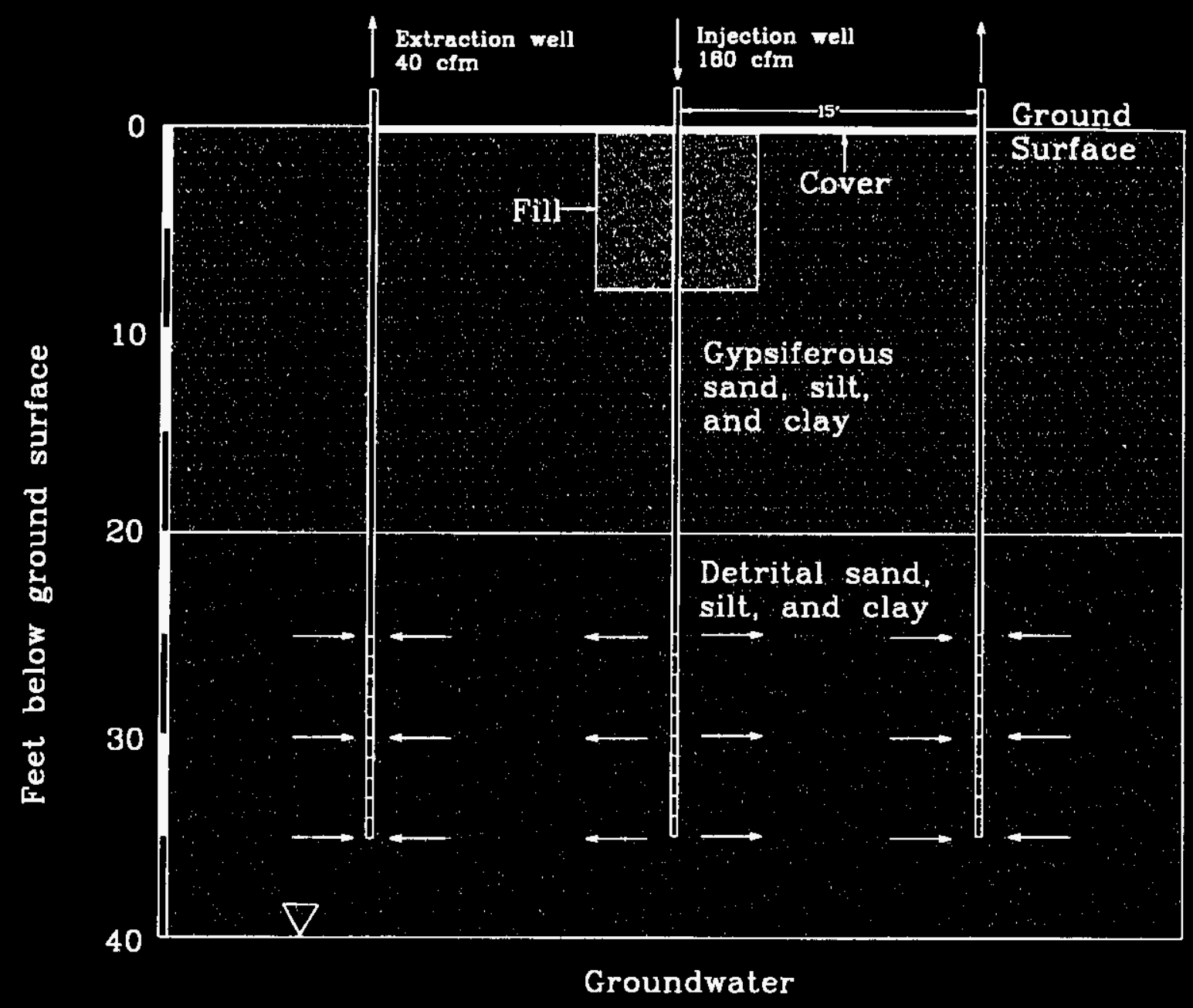


WHC-SD-EN-TP-055, Rev. 0

Chemical sensors and flow meters will be situated in the injection and extraction gas streams to provide a record of hydrogen sulfide gas concentrations and flow rates. Concentration levels of hydrogen sulfide in the extraction streams will be utilized as a parameter for gauging treatment progress; treatment will be assumed to be complete within a given sector of the site when hydrogen sulfide breakthrough is observed in the corresponding extraction well. The flow rate of each extraction well will be adjustable through an associated valve, thus allowing uniform treatment of the site by controlling movement of the chemical reaction front.

\subsection{INSTALLATION AND OPERATION}

To accurately determine the depth range of the zone to be remediated, a better knowledge of the spatial distribution of chromium contamination and geotechnical characteristics is needed. Additional subsurface samples will be collected by Geoprobe ${ }^{\mathrm{TM}}$ (Geoprobe is a trademark of Geoprobe Systems, a division of KEJR Engineering, Inc.) or auger drilling for determination of hexavalent chromium concentrations and for laboratory measurement of permeabilities (Section 3.2). Figure 5 indicates pre-test sampling locations and also the locations where soil samples will be obtained at the completion of the demonstration.

The central injection borehole will also be installed for the acquisition of gas flow and permeability information by performing air extraction/injection or straddle packer tests (Johnson et a1. 1990, Marley et a1. 1989, and Phalen 1994). These tests will serve to define the permeability variations at the site. The results of the sampling and well testing information combined with modeling efforts will be utilized to determine the optimal position of the screened intervals in the injection and extraction wells. The remainder of the network will be installed after a final network design is defined. The holes drilled to complete the network will also be utilized to obtain additional soil samples for site characterization purposes.

A tracer test will be performed with SF $_{6}$ after the wellfield network is installed (01schewski et a1. 1995 and Rohay 1993). Tracer tests are commonly utilized to assess diffusional rates and radius of influence. In the wellfield tracer test, surface area samples will also be collected and analyzed as a leaktest to assess if gas is escaping from the subsurface flow cel1, borehole seals, wellhead fittings, surface lines, or the injection/extraction system. Analys is of tracer levels in the extraction wells will be utilized to determine in gas moves through the subsurface flow cell in a homogeneous manner or if flow barriers or channels exist. This test will also be utilized to verify flow characteristics of the network predicted from modeling activities (i.e., flow rate as a function of head and soil permeability). The information collected from the tracer test will serve to verify that gas injection and recovery can be adequately controlled and will be utilized to define wellfield pumping parameters for the treatment phase.

Injection of the treatment gas will be initiated after successful completion of the wellfield tracer test. All of the extraction wells will operate at full flow until hydrogen sulfide breakthrough is detected. As breakthrough occurs at an individual wel1, flow rate will be decreased by partially closing the valve at that well. This will direct more hydrogen sulfide to the 
WHC-SD-EN-TP-055, Rev. 0

remaining we11s. Treatment will be completed when breakthrough is achieved at all extraction wells. Breakthrough will be specified as complete when $C / C_{0}$ equals or exceeds 0.6 , where $C$ is the treatment gas concentration during a particular time during the demonstration and $C_{0}$ is the initial treatment gas concentration (e.g., if 300 ppm hydrogen sulfide is injected, breakthrough is achieved at an extraction well when $180 \mathrm{ppm}$ hydrogen sulfide is present in the extracted gas stream). This value of $C / C$ o is based on a $20 \%$ dilution factor predicted by modeling results, and data from laboratory tests that indicate $70 \%$ breakthrough is sufficient to achieve $90 \%$ treatment. Several days of additional treatment may also be undertaken to allow diffusion into tighter zones to occur, if deemed necessary.

After satisfactory breakthrough is achieved at all extraction wells, excess hydrogen sulfide will be purged from the system by pumping in air. Purging will be completed when $<10 \mathrm{ppm}$ hydrogen sulfide is detected in the extracted gas streams from all network wells.

Soil samples will also be obtained by Geoprobe ${ }^{\mathrm{TM}}$ or auger drilling after completion of the demonstration and characterized to determine treatment effectiveness (Figure 5). These samples will be analyzed for total chromium and hexavalent chromium as described in Section 3.2.

\subsection{SAFETY AND PERFORHANCE MONITORING OF FIELD DEMONSTRATION}

An Operating Log will be maintained at the demonstration site that will include process monitoring information, data collection notes, and general observation notes. Performance of the gaseous reduction demonstration system will be monitored at least three times a week by site personnel. Daily monitoring will be performed during the first week of the gaseous reduction demonstration. Process monitoring information will be also be acquired and stored by data logger on a continuous basis. This information will be downloaded to a computer for long-term electronic storage.

The gaseous reduction system will also be continuously monitored by an automatic security system. System shutdown will take place in the event that any one of the following situations occur: 1) someone enters the exclusion zone while gas is being injected, 2) vacuum or injection pressure is lost, or 3) site monitoring equipment indicates elevated levels of hydrogen sulfide. other interlocks may be added as deemed necessary. The security system will notify, by cellular phone, the Field Team Lead in the event that power is automatically shutdown. Appropriate corrective action measures will be taken prior to restarting the system.

Selenoid valves associated with the treatment gas cylinders will automatically shutdown in the event of a power failure, ensuring that gas injection is suspended. A generator will be utilized as a power backup source for the system.

The goal of this field test is to demonstrate the transformation of mobile chromate contamination to a nontoxic immobile chromic solid product in unsaturated soils. Collection of system monitoring data will be used to determine the role of process variables on system performance, whereas preand post-test soil sampling will define the effectiveness of remediation. 
WHC-SD-EN-TP-055, Rev. 0

Monitoring the influent and effluent gas streams for hydrogen sulfide concentrations will be used to determine the effectiveness of the gaseous reduction demonstration. Initially, there should be a fairly constant rate of chromium reduction in the site soils for some period of time followed by exponential decline in the rate of reaction as the zone is remediated. This will be manifested by breakthrough of hydrogen sulfide at the extraction we11s. A monitoring system will be used that can provide real time data regarding the composition of the gas treatment system and flow rates. It is anticipated that the bulk of gas stream concentration data will be collected using electrochemical sensors. The primary system components will be connected into a computer or data logger which will maintain a record of systems operational and monitoring information.

Monitoring of the scrubber stack will also be performed with an electrochemical sensor to verify that regulatory release 1 imits of hydrogen sulfide are not exceeded. An operation manual will be prepared for the gas treatment system that will include procedures for monitoring of the level of hydrogen sulfide in scrubber stack emissions. An alarm will be sounded if hydrogen sulfide is emitted from the scrubber stack in excess of the prescribed limit.

Several additional hydrogen sulfide sensors will be located on site and down wind to ensure compliance with site safety and air monitoring requirements. Site monitors will function independently of the system and will have backup battery power.

\subsection{DATA QUALITY OBJECTIVES AND PERFORMANCE EVALUATION}

The overall objective of this technology demonstration is to evaluate the performance, safety, environmental acceptability, and cost effectiveness of the in situ gas treatment approach to the remediation of chromate-contaminated soil. This evaluation should serve as a basis for comparing the technology with conventional remediation approaches such as excavation.

The formulation of data quality objectives is used as a planning tool to identify specific data parameters to be measured or collected during the field demonstration and to develop a data collection strategy that will provide the quantity and quality of data needed to support this overall objective. The following sections describe the data quality objectives and operating parameters associated with acquisition of demonstration information required to achieve this goal.

\subsection{SPECIFIC DEMONSTRATION OBJECTIVES}

The following specific objectives for the field demonstration have been formulated from the Demonstration Objectives Work Sheet (Attachment 2 of Thornton and Miller 1995 with modifications): 
WHC-SD-EN-TP-055, Rev. 0

- The degree of treatment of contamination achieved during the field demonstration will be determined by sampling and characterization of site soils following completion of the test. This will include performance of leach tests on pre- and post-treatment site soil samples to assess the degree of immobilization of chromium achieved. Performance goals will be established that will include consideration of applicable cleanup standards.

- An important objective of the field test is to demonstrate that gas emissions can be maintained at an acceptable level. Site monitoring activities will be conducted during the demonstration to evaluate how effectively the treatment gas is controlled. A scrubber will be utilized during the field demonstration to remove excess hydrogen sulfide present in the extraction stream.

- It is also important to demonstrate that gas movement can be directed through the site under controlled conditions and excess treatment gas can be effectively recovered. Flow cell modeling and laboratory testing activities are being conducted to develop a well network design that will minimize fugitive emissions. A tracer test will be conducted with sulfur hexafluoride prior to initiating the demonstration in order to verify the system design, optimize operational parameters, and ensure control of gas

movement within the site. A barrier will also be placed over the site during the demonstration to minimize escape of the treatment gas mixture.

- Site monitoring data will be collected during the demonstration to assess worker exposure to treatment gas and to establish requirements associated with using the technology.

- Site monitoring data will also be used to assess potential risk to public health and safety associated with use of the technology. This includes the risk associated with accidents and routine releases of the treatment gas. Risk associated with transportation of equipment and materials should also be assessed in conjunction with the demonstration.

- Ecological and aesthetic impacts of using the technology will be assessed during the demonstration. This includes any effects on the biota associated with the waste site and any occurrences of detectable hydrogen sulfide odor during the demonstration. Energy demands (fuel or electrical power consumption) will also be assessed.

- Site characterization activities will be conducted following the demonstration to assess the capacity for unrestricted use of the contaminated area and any need for ongoing control and monitoring activities. 
WHC-SD-EN-TP-055, Rev. 0

- Experience will be gained from the demonstration regarding the primary regulatory requirements that must be addressed. Chemicalspecific requlatory requirements, such as emission limits, will be determined. Data collected from the demonstration will be used to assess the degree to which these requirements were met.

- Data shall be collected during the demonstration to support an analysis of capital costs and operating and maintenance costs associated with the technology.

- An assessment of the readiness of the technology for fullscale deployment will be provided following completion of the demonstration. The demonstration will also provide information regarding the length of time required to achieve required performance goals.

\subsection{SOIL SAMPLING AND CHARACTERIZATION REQUIRENENTS}

Site soil sampling will be performed by Geoprobe ${ }^{T M}$ or auger drilling for field screening and laboratory analysis, geotechnical characterization, lithologic description, and laboratory treatability studies. Pre- and posttreatment soil sampling locations are presented in Figure 6. Samples will be collected at five foot intervals at each location. The Technology Demonstration Coordinator will prepare a sampling and analys is plan in consultation with the Principal Investigator before undertaking site soil sampling activities.

Prepared labels will be affixed to sample containers. Information included on the label will include:

$\begin{array}{ll}\text { - } & \text { Project name } \\ \text { - } & \text { Nollecting date } \\ \text { - } & \text { Sample of sampler } \\ \text { - } & \text { Nature of material } \\ \text { - } & \text { Requested analyses or test. }\end{array}$

Glass or plastic/polyethylene containers are preferred for storage of soil samples. If the container is not inert (e.g., meta1), a plastic liner will be placed in the container before transferring the soil into it. Sample containers to be transported must be closed and sealed with evidence tape. Radiation from the exterior of the sample container sha11 meet U.S. Department of Transportation (DOT) regulatory requirements. (The waste site is nonradioactive.) Samples shipped to WHC for testing or analys is shall be shipped in accordance with EII 5.1, Chain of Custody/Sample Analys is Request, and EII 5.11, Sample Packaging and Shipping, of WHC (1991).

Analysis of soil samples will be performed by qualified laboratories under contract to SNL. In addition, WHC will perform soil analyses to support an assessment of demonstration treatment goals (e.g., water leachable hexavalent chromium). Commonly used EPA SW846 procedures (EPA 1992) provide chemical data with sufficient accuracy and precision to satisfy the performance goals 
WHC-SD-EN-TP-055, Rev. 0

(data quality objectives) as defined above. The following SW846 procedures will be used in support of the demonstration:

- Method 6010 - Inductively coupled plasma emission spectrometry (ICP) for cations/metals

- Method 300.0 - Ion chromatograph (IC) for anions

- Method 7196 - Chromium (VI).

Immobilization of hexavalent chromium will be determined by leaching with deionized water (Thornton et al. 1994) and analys is using Method 7196 or equivalent. In addition, the Toxic Characteristic Leaching Procedure (TCLP; Sw846 Method 1311) will be employed as appropriate. Table 1 provides the analytical methods, quantitation limits, and precision and accuracy guidelines associated with determination of hexavalent and total chromium present in the soils.

A minimum of one equipment blank shall be collected at the completion of sampling each day and analyzed to assess and document the levels of contamination, if any, contributed from sampling equipment. A minimum of one duplicate soil sample shall also be collected for analys is each day samples are collected. The purpose of collecting duplicate samples is to assess and document overall analytical precision.

Field screening of soil samples for hexavalent chromium shall also be conducted. This will involve placing 5 grams of soil in a bottle and adding $100 \mathrm{ml}$ of deionized water. The bottle will then be agitated for one hour and the fluid decanted and filtered before analysis. The water leachate will be analyzed with a spectophotometer in accordance with EPA Method 7196.

Geotechnical measurements to be performed on pre-treatment soil samples will. include soil moisture determination, bulk density, and permeability (WHC 1990). In addition, soil moisture determination will be performed on post-treatment samples.

\subsection{GAS ANALYSIS REQUIREMENTS}

Electrochemical sensors will be utilized will be utilized to measure hydrogen sulfide concentrations associated with the injection and extraction gas streams and the scrubber stack off-gas. These sensors will also be used as site and personal protection monitors. The detection 1 imit of hydrogen sulfide monitors to be used for measuring gas concentrations associated with the treatment system is $1 \mathrm{ppm}$ and the range is 0 to $200 \mathrm{ppm}$. Precision is these sensors is commonly $\pm 1 \mathrm{ppm}$ and accuracy shall be maintained at $\pm 5 \mathrm{ppm}$ or better, as verified by gas calibration standards.

Hydrogen sulfide concentration measurements associated with the treatment system and scrubber stack will be downloaded to a computer from a datalogger, and will recorded in field notebooks on a daily basis for the first week of treatment and at least several times a week thereafter. Breakthrough measurements at the extraction network wells will be recorded in a field notebook at least several times a week. 
Table 1. Chromium Analytical Methods, Analytes of Interest, Quantitation Limits, and Precision and Accuracy Guidelines.

\begin{tabular}{|c|c|c|c|c|}
\hline Analyte & $\begin{array}{c}\text { Analytical } \\
\text { Method }\end{array}$ & $\begin{array}{c}\text { Practical } \\
\text { Quantitation } \\
\text { imit Soil }^{\mathrm{a}}\end{array}$ & Precision $^{\mathrm{b}}$ & Accuracy $^{\mathrm{b}}$ \\
\hline $\begin{array}{c}\text { Hexavalent } \\
\text { Chromium }\end{array}$ & $7196^{\mathrm{c}}$ & $0.5 \mathrm{mg} / \mathrm{kg}$ & \pm 20 & $75-125$ \\
\hline $\begin{array}{c}\text { Total } \\
\text { Chromium }\end{array}$ & $6010^{\mathrm{c}}$ & $2 \mathrm{mg} / \mathrm{kg}$ & \pm 20 & $75-125$ \\
\hline
\end{tabular}

avalues are to be considered requirements in the absence of known or suspected analytical interferences that may hinder achieving the limit by the analytical laboratory.

brecision is expressed as relative percent difference; accuracy is expressed as percent recovery. These 7 imits apply to sample results greater than five times the target quantitation limit and are to be considered requirements in the absence of known or suspected analytical interferences that may hinder achieving the limit by the analytical laboratory.

${ }^{c}$ Methods specified are EPA (1992) or equivalent. 
WHC-SD-EN-TP-055, Rev. 0

Sulfur hexafluoride concentrations associated with the tracer test will be measured with a gas chromatograph equipped with an electron capture or flame photometric detector (accuracy: $\pm 10 \%$, precision : $\pm 5 \%$; Rohay 1993 ). Gas samples associated with this test will be collected using polyethylene syringes.

\subsection{TREATABILITY TESTING REQUIREMENTS}

A laboratory treatability study will be conducted on several soil samples collected at the site. These tests involve packing a soil sample into a column and passing the treatment gas mixture through the column until treatment has been completed. The column is then leached and the leachate analyzed. Immobilization of the treatment procedure can be assessed by comparing the concentration of hexavalent chromium in the treated sample leachates versus untreated controls (Thornton et al. 1994, and WHC 1990 and 1993).

The laboratory gas treatment system utilizes electronic flow controllers to generate a specified gas mixture while maintaining a constant flow rate of 2.5 $\mathrm{L} / \mathrm{min}$. Electrochemical gas sensors allow measurement of hydrogen sulfide concentrations of the inlet and outlet sides of the packed soil column. This information will be utilized to determine the breakthrough characteristics of hydrogen sulfide during soil treatment. The amount of hydrogen sulfide consumed by the soil provides an indication of treatment time requirements and the mass of hydrogen sulfide required per unit mass of soil. Thus, data associated with treatment gas breakthrough can be utilized to predict required treatment time to complete the demonstration.

Each test requires approximately 250 grams of soil. At least two treatment tests will be conducted on each soil sample (100 ppm and 200 ppm hydrogen sulfide in air). A leach test will also be conducted on an untreated control for each soil sample tested. It may thus be necessary to composite soil samples to obtain portions of about 1 kilogram each in order to obtain sufficient material to undertake these tests. Two soil composites will be tested in this manner (six tests).

Breakthrough curve data will be utilized to estimate the mass of hydrogen sulfide required to achieve treatment per unit mass of soil at these gas concentrations. The treated soil columns will then be leached to assess treatment effectiveness. The untreated controls will also be leached for comparison to the treated samples. Treatability tests conducted with chromate-contaminated soils indicate that $90 \%$ or better immobilization of hexavalent chromium should be achieved.

The gas sensors used to monitor the concentration of the treatment gas mixture must be able to measure concentrations in the range 1 to $200 \mathrm{ppm}$ hydrogen sulfide. These sensors shall be calibrated with a $100 \mathrm{ppm}$ hydrogen sulfide calibration standard mixture before each test.

Analys is of leachate samples for hexavalent chromium shall be performed in accordance with SW846 Method 7196 by personnel in the testing laboratory. At least one sample from each test will be analyzed in duplicate to assess precision. Certified standards will be utilized to calibrate the 
spectrophotometer and check standards will be analyzed to verify that recovery in the range 90 to $110 \%$ is maintained. A detection 1 imit of $0.05 \mathrm{mg} / \mathrm{L}$ or 7 ess for hexavalent chromium is expected.

\subsection{OPERATING PARAMETERS AND PERFORMANCE EVALUATION}

\subsubsection{Expected Results}

The field demonstration will provide information to assess the feasibility of conducting gaseous reduction remediation in unsaturated soils under field conditions. Evaluation of the effectiveness of this remediation technique will be performed by analys is of pre- and post-test soil samples. A cost analysis will also be made of the technology based on the performance data collected during the field test.

\subsubsection{Surface Treatment System Performance}

The surface treatment system must be capable of producing a mixture of hydrogen sulfide diluted in air at a constant concentration and flow rate for period of up to several months. A variation of $5 \%$ or 1 ess shall be deemed acceptable for these parameters. Injection and extraction pressures and temperatures will al so be monitored during the demonstration. A datalogging system will be utilized to maintain a record of this information. In addition, system performance data will be recorded in the field notebook at least twice a week as a backup record.

A record of the performance of the gas scrubber will also be maintained during the demonstration. In particular, any releases of hydrogen sulfide from the scrubber stack will be documented. A record will also be maintained of scrubber $\mathrm{pH}$ and the frequency of caustic solution changeout.

\subsubsection{Gas Flow Characteristics of the Wellfield Network}

An engineering study has been conducted to define a subsurface treatment gas injection/extraction network that could be employed to remediate a site (Foster Wheeler 1995 and Thornton and Miller 1995). Site characterization data associated with a waste site located at the Chemical Waste Landfill near Sandia National Laboratories were used in this study for modeling purposes.

The USGS MODFLOW (MCDonald and Harbaugh 1988) and MODPATH (Pollock 1989) groundwater modeling software programs, with modifications for gas flow, and the AIR3D (Joss and Baehr, in press) gas flow modeling code were employed in the study to evaluate the gas flow-cell characteristics associated with the demonstration. A total of eight test cases were considered. The base case (Case 1) configuration, which is similar to the network to be employed in this field test, consisted of a central borehole that is screened from 7.6 to $15.2 \mathrm{~m}$ ( 25 to $50 \mathrm{ft}$ ) below ground surface. The extraction network was composed of six wells with a radius of $4.6 \mathrm{~m}$ (15 ft), with an impermeable cover placed on the ground surface within the network. Treatment gas was injected into this borehole at a pressure of 36 inches water gauge $(1.09 \mathrm{~atm}$ absolute). The six extraction wells were also screened from 25 to 50 feet and operated at a vacuum of -6.75 inches water gauge $(0.98 \mathrm{~atm}$ absolute). The model predicted an injection flow rate of $233 \mathrm{cfm}$ for the injection well and 
WHC-SD-EN-TP-055, Rev. 0

an extraction flow rate of $48 \mathrm{cfm}$ per extraction well, for a total extraction flow rate of $288 \mathrm{cfm}$. This corresponds to $19 \%$ dilution by extraction of air from outside the well field.

Model ing results also indicated that adequate capture/confinement of the injected hydrogen sulfide should be achievable for the base case. This is illustrated in Figure 7, which displays the head contours and flow paths predicted for the injection zone (layer 4 ) of the base case gas flow model.

While the characteristics of the White Sands demonstration site are somewhat different than that of the modeling cases ran to date, it is believed that the results discussed above are a realistic approximation of gas flow parameters expected for the site. Additional modeling runs will be performed as more site data becomes available. In addition, a vacuum step test and a full wellfield network tracer test will be performed at the site to verify and calibrate the gas flow model.

Data to be collected during the treatment phase of the demonstration that will be utilized to evaluate wellfield performance shall consist of hydrogen sulfide concentrations and flow rates at each extraction well. Injection parameters shall be obtained from monitoring of the treatment system (Section 3.4.2). Flow rates will be adjusted at each extraction wellhead during the demonstration in a effort to achieve satisfactory treatment of the entire flowcell volume, as indicated by hydrogen sulfide breakthrough values of $\mathrm{C} / \mathrm{C}_{0}$ of at least 0.6 .

\subsubsection{Gas Treatment Parameters for Chromate-Contaminated Soils}

As discussed in Section 3.3, treatability tests will be conducted on soil samples waste site to verify the treatment process and obtain preliminary estimates of unit treatment parameters. Results of past treatability tests can also be utilized for an initial as sessment, however. Thus, experiments using a bench scale version of the gas flow system have recently been conducted by the Westinghouse Hanford Company with soil collected from a chromate-contaminated disposal cell located in the Chemical Waste Landfill near Sandia National Laboratories. The results of these tests indicate that treatment of contaminated soil with a $100 \mathrm{ppm}$ hydrogen sulfide gas mixture is effective in immobilizing hexavalent chromium. Thus, a treatment efficiency of $99.5 \%$ was observed for a contaminated soil sample containing $186 \mathrm{ppm} \mathrm{Cr}$ (VI) and $98.5 \%$ for a sample containing $530 \mathrm{ppm} \mathrm{Cr}(\mathrm{VI})$, obtained at a depth of $6.1 \mathrm{~m}$ and $9.2 \mathrm{~m} \mathrm{(20}$ and $30 \mathrm{ft}$ ), respectively. If the treatment parameters obtained from the bench scale tests are applicable at the field scale to the White Sands site, then similar treatment efficiencies may be anticipated for the field demonstration. Laboratory testing activities also indicate that reaction rates are favorable and treatment efficiencies are largely independent of gas concentrations and soil moisture content.

The time required to achieve complete treatment during the demonstration can be estimated on the basis of the mass of soil associated with the waste site, the mass of hydrogen sulfide required per unit mass of soil, and the rate of application of hydrogen sulfide to the site. If the zone targeted for treatment is 10 feet thick and 30 feet in diameter, the volume of soil involved is 7069 cubic feet. Assuming a bulk density of $1101 \mathrm{~b} / \mathrm{ft}^{\frac{3}{3}}$, 
WHC-SD-EN-TP-055, Rev. 0

Figure 7. Injection Zone Head Contours with Particle Tracks Overlaid.

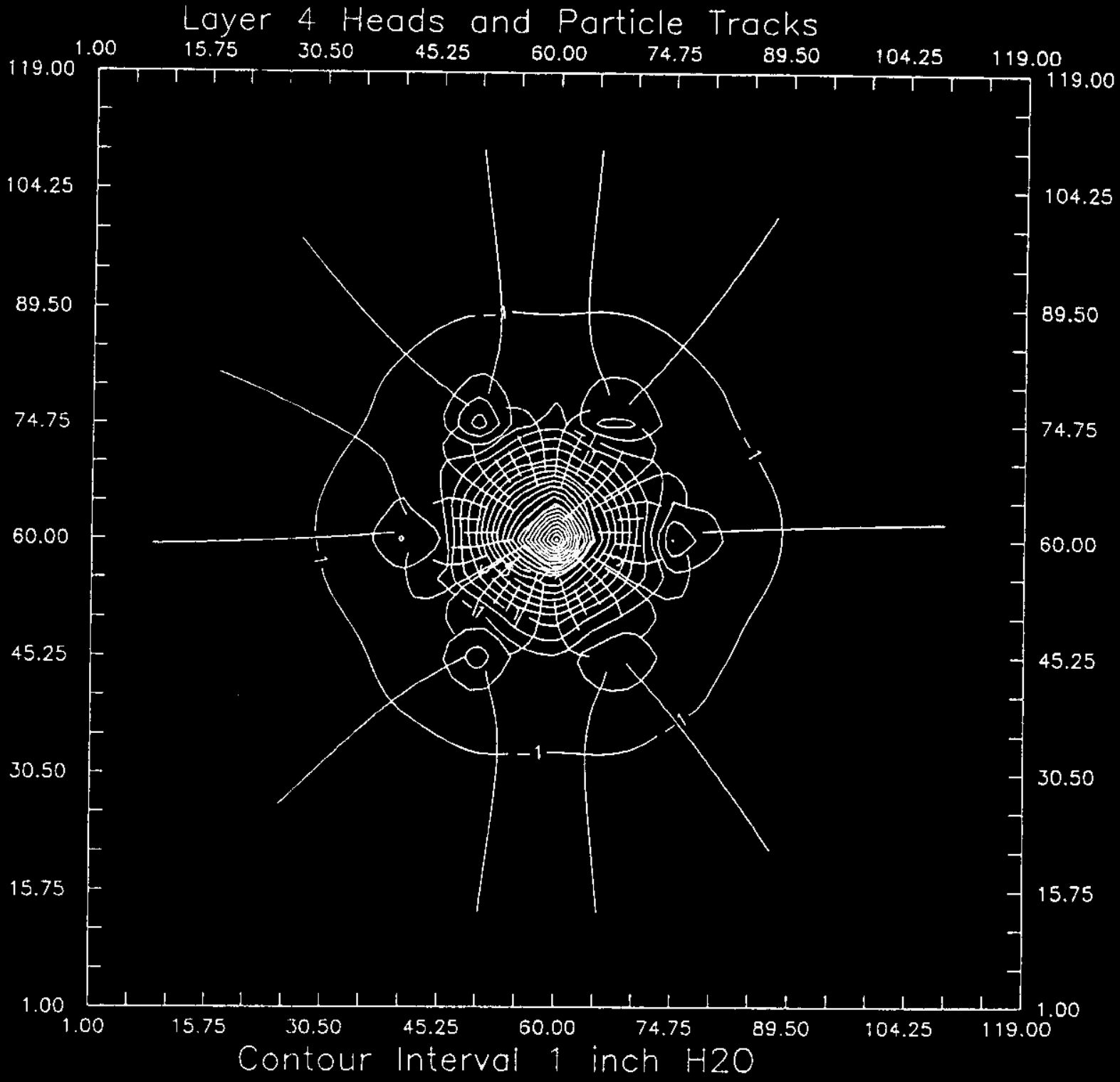


approximately $7.78 \times 10^{5}$ lbs of soil is located in this interval. Soil treatment test results for the Chemical Waste Landfill samples indicated that about 0.0005 lbs of hydrogen sulfide are required to treat one pound of soil. Thus, approximately 389 lbs of hydrogen sulfide is required to treat the site, assuming this ratio applies. If the treatment gas is injected into the site as a $100 \mathrm{ppm}$ hydrogen sulfide mixture at a flow rate of $100 \mathrm{cfm}$, the time required to achieve breakthrough is about 305 days. However, since the treatment time required is inversely proportional to gas concentration and flow rate, the time associated with treatment can be reduced by increasing the hydrogen sulfide concentration of the injection gas stream or by injecting at a higher flow rate. The relationship between treatment time and gas concentration or flow rate is presented in Figure 8 . This diagram illustrates, for example, that treatment could be accomplished in about five months by injecting $200 \mathrm{ppm}$ hydrogen sulfide at a flow rate of $100 \mathrm{cfm}$ or by injecting $100 \mathrm{ppm}$ hydrogen sulfide at a flow rate of $200 \mathrm{cfm}$. Conversely, injection of $500 \mathrm{ppm}$ hydrogen sulfide at a flow rate of $400 \mathrm{cfm}$ would require only about 2 weeks.

It is proposed that a gas concentration of at least $300 \mathrm{ppm}$ hydrogen sulfide be applied at a flow rate of $200 \mathrm{cfm}$ during the demonstration. For these conditions, the treatment time required should be several months or less.

Homogeneity of treatment at the field scale is dependent on achieving uniform distribution of the treatment gas stream. This can be enhanced to a large degree by modeling of gas flow in conjunction with detailed site characterization data. Adequate monitoring and control of breakthrough at the network extraction wells during the field test should also serve to optimize treatment efficiency and homogeneity. Final evaluation of immobilization efficiencies and assessment of the uniformity of site treatment will depend, however, on retrieval and analysis of soil samples following completion of the field demonstration.

\subsubsection{Preliminary Cost Analys is}

A preliminary estimate of capital, operating and maintenance, and waste disposal costs associated with the field demonstration are summarized in Table 2. The total cost associated with this analysis assumes a project of two years duration. Major activities include design and fabrication of the gas treatment system, preparation of permits and supporting documentation, performance of treatability tests and site characterization activities, installation of the well network, performance of field tracer and treatment tests, and completion of post-test site restoration activities. Some of the costs associated with development of the technology have not been included in order to obtain unit treatment costs that are directly related to the actual remediation effort.

Standard 4-in diameter vadose zone wells will be used in the wellfield network. The cost of a conventional well to be installed is approximately $\$ 50 / \mathrm{ft}$ for drilling and $\$ 30-100 / \mathrm{ft}$ for installation of 2 to 6 -in diameter casing. Decommissioning of the wells at the completion of the project must also be considered. The cost to remove the casing and grout the borehole is typically in the range of one-third the cost of installation. For the 35-ft deep wells needed at the site, the cost per conventional well is estimated to be $[(\$ 50 / \mathrm{ft})(35 \mathrm{ft})+(\$ 65 / \mathrm{ft})(35 \mathrm{ft})](1.33)=\$ 5353$. If seven conventional wells 
WHC-SD-EN-TP-055, Rev. 0

Figure 8. Hydrogen Sulfide Concentration versus Treatment Time at Various Gas Flow Rates.

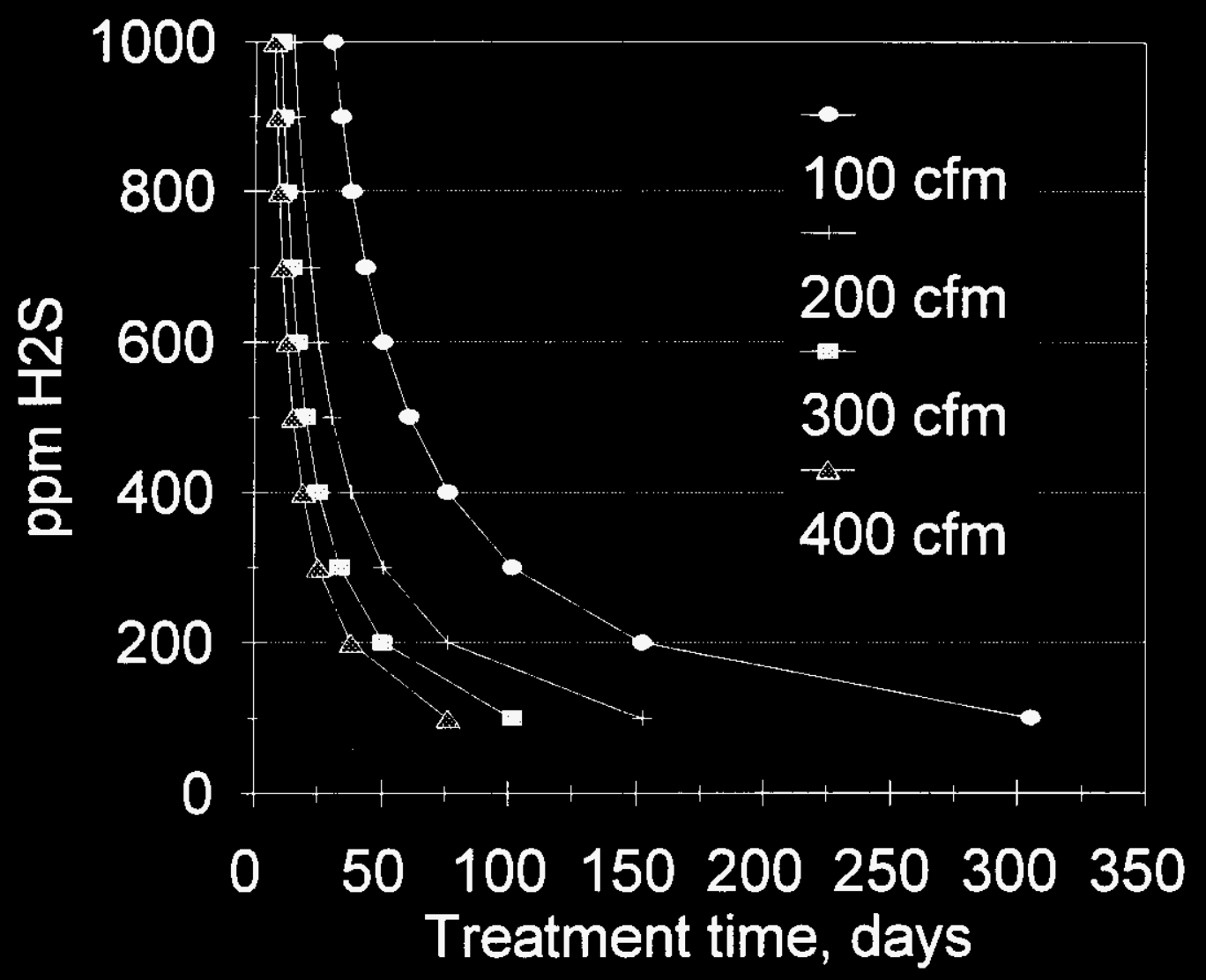




\section{Table 2. Summary of Estimated Technology Costs}

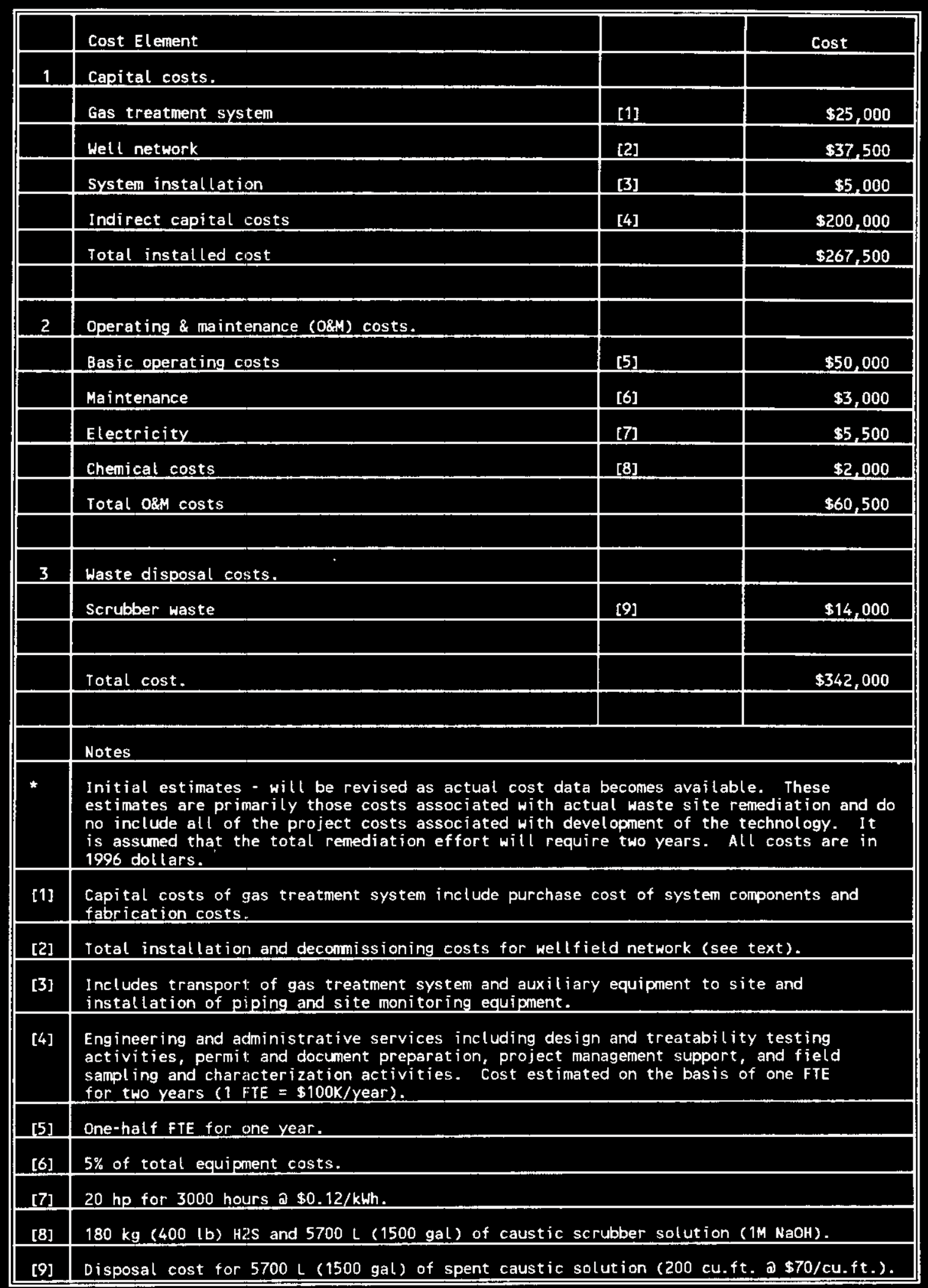


WHC-SD-EN-TP-055, Rev. 0

are installed for injection and extraction, the total cost for the wellfield will be about $\$ 37,500$.

The information obtained from the cost analysis provides a basis for calculating unit treatment costs associated with the in situ gas treatment approach. The total volume associated with the demonstration is 30 feet in diameter and has a depth of about 40 feet, corresponding to 28,274 cubic feet or 1047 cubic yards. Based on a total treatment cost of $\$ 342,000$, the unit treatment cost is $\$ 327$ per cubic yard or $\$ 217$ per ton of soil. This is roughly comparable to unit costs for excavation of contaminated soil with indrum stabilization/solidification ( $\$ 200$ per cubic yard) but higher than in situ mixing ( $\$ 10$ to $\$ 20$ per cubic yard, Cullinane and Jones 1989). The estimated unit cost associated with the field demonstration is also higher than that generally reported for in situ vapor extraction projects $(\$ 10$ to

$\$ 150$ per ton, Udwari and Chartrand 1992; \$47.12 per ton, EPA 1989; \$10 to \$50 per cubic yard, Marley et al. 1989).

It is 1 ikely that unit treatment costs associated with application of in situ gas treatment will be less at many sites, however, since some of the initial engineering and capital costs will not reoccur and the economics should improve at a larger scale. A radius of influence of $50 \mathrm{ft}$, for example, is routinely attained by vapor extraction wells (Johnson et a1. 1990). Thus, the configuration associated with this demonstration could potentially be utilized to remediate a site that is 100 feet in diameter. If we assume that the site is treated to a depth of 40 feet, the total waste site volume would be 11,636 cubic yards. This corresponds to a unit cost of $\$ 29.39$ per cubic yard if the total treatment cost remains $\$ 342,000$. It is thus possible that ultimate unit costs associated with in situ gas treatment for certain sites may be about $10 \%$ of unit costs associated with excavation and similar in unit costs to other in situ remediation approaches.

\subsection{REGULATORY COMPLIANCE}

This section discusses the regulatory compliance requirements that generally apply for a technology demonstration conducted at a RCRA waste site. The major federal and state environmental laws to be considered at a RCRA Research, Development, and Demonstration (RD\&D) unit include NEPA; the Resource Conservation and Recovery Act (RCRA); the Clean Air Act; and the Emergency Planning and Community Right-to-Know Act. No requirements under the Clean Water Act or the Safe Drinking Water Act are expected. Final determination of applicable requirements is the responsibility of the WSMR Site Manager. The SNL Technology Demonstration Coordinator will prepare the permits and documentation necessary to satisfy regulatory compliance requirements.

\subsection{NATIONAL ENVIRONMENTAL POLICY ACT}

The objective of NEPA is to ensure that federal agencies give appropriate consideration to environmental impacts in their decision-making processes. All major federal actions require supporting NEPA documentation. 
In accordance with the NEPA, an evaluation of potential environmental impacts will be performed. It is assumed that the only aspect of concern associated with this demonstration will be the actual injection of diluted hydrogen sulfide into the site. This will occur after site characterization activities and wellfield tracer tests have been completed that demonstrate adequate control and capture of the treatment gas can be accomplished. The primary NEPA action required involves preparation of a NEPA Environmental Assessment (EA).

\subsection{RESOURCE CONSERVATION AND RECOVERY ACT}

RCRA Subtitle $C$ requirements apply to the generation, accumulation, treatment, storage, and disposal of hazardous/dangerous waste. Generally speaking, any waste generated during the demonstration will fall under a treatment permit as required by the Hazardous and Solid Waste Amendments (HSWA) of 1984 to RCRA for solid waste management units (SWMUs). Alternatively, the site may qualify as a RCRA Corrective Action since it is anticipated that remedial benefits will result from the demonstration.

Any hazardous waste generated as a result of the in situ gas treatment demonstration will be handled in accordance with WSMR waste management procedures, as indicated by the Site Manager. This will include soil excavated during drilling operations and wastes generated by the gas treatment system. Excavated soil will be drummed and later analyzed to determine proper disposal procedures. Chromium is the only contaminant present at the site which may be at concentration levels of concern from a solid waste management standpoint (e.g., above TCLP action levels). The major waste stream generated by the gas treatment system will be expended caustic solution from the scrubber. A small amount of water may also be recovered from the water knockout tank. These liquids will be disposed of as normal RCRA wastes.

\subsection{CLEAN AIR ACT}

The in situ gas treatment technological approach is designed to remediate waste site soils without release of any gas residual (hydrogen sulfide) to the atmosphere. This is accomplished through capture of residual by the extraction wells and scrubbing of hydrogen sulfide from the exhaust by a scrubber. The scrubber stack and the site will be monitored to ensure that no significant emission of hydrogen sulfide occurs during the demonstration. If concentrations of emissions exceed preset levels, as specified by a site air permit, gas injection will cease and corrective actions taken such that there will be no continued release into the environment.

VOCs are not expected to be present in site soils. An organic vapor analyzer will be available onsite to verify this, however.

\subsection{EMERGENCY PLANNING AND CONMUNITY RIGHT-TO-KNOW ACT}

The gas treatment system will utilize hydrogen sulfide gas and sodium hydroxide solution during operation. Material Safety Data Sheets (MSDSs) for these substances will be available at the test site. These chemicals will be 
WHC-SD-EN-TP-055, Rev. O

reported in accordance with the Emergency Planning and Community Right-to-Know Act.

\subsection{SITE COMPLIANCE}

This section identifies general site compliance requirements for the field demonstration. The WSMR Site Manager will provide direction regarding specific requirements applicable to HELSTF (biological/cultural/archeological reviews, construction or excavation permits, sample shipment, security and site access requirements, etc.). The Technology Demonstration Coordinator will have responsibility for ensuring compliance with these requirements.

\subsection{SAFETY}

Operational safety will be discussed in a operation manual for the gas treatment system. Features of the system's operation and details of the demonstration have also been evaluated in a hazards analysis and safety assessment of the planned demonstration activities. This assessment considered a worst-case scenario involving the catastrophic release of the contents of a hydrogen sulfide cylinder.

The in situ gas treatment demonstration field activities will be governed by a Site-Specific Health and Safety Plan, as required by 29 CFR 1910.120. The plan will be located at the waste site and will include the following information:

- Job Hazards Analysis and Safety Assessment

- Training Requirements

- Personal Protective Equipment

- Medical Surveillance Requirements

- Personnel Monitoring Strategy/Action Levels

- Site Control

- Decontamination Procedures

- Emergency Response Action

- Confined Space Entry Procedures

- Spil1 Containment Program.

Certain aspects of the Site-Specific Health and Safety Plan are not applicable for the field demonstration (e.g., decontamination procedures and confined space entry procedures), as noted in the plan.

MSDSs will be located onsite for any hazardous chemicals employed (e.g., hydrogen sulfide and sodium hydroxide). Everyone working at the site during the treament phase of the demonstration will be issued a personal hydrogen sulfide monitor. These monitors will be set to sound an alarm if 10 ppm hydrogen sulfide is detected. Several site monitors will also be located onsite and downwind and will sound a site-wide alarm if hydrogen sulfide is detected at levels specified by the Site-Specific Health and Safety Plan. These monitors will operate independently of the treatment system and will have backup battery power in case of a site power failure. An emergency 
WHC-SD-EN-TP-055, Rev. 0

response action will be specified in the Site-Specific Health and Safety Plan if a significant release of hydrogen sulfide occurs.

\subsection{TRAINING}

Operational Safety and Health Administration (OSHA) training for personnel working at hazardous waste sites plus all relevant training specified by WSMR will be required for any personnel entering the exclusion zone around the site during drilling or other demonstration activities. Job-specific training, including Hazardous Communication Training for hydrogen sulfide, will be provided for personnel operating the gas treatment system or otherwise involved in technical activities associated with conducting the demonstration. Safety training requirements will be 1 isted in a Site-Specific Health and Safety Plan.

\subsection{WASTE GENERATION AND MANAGEMENT}

Potentially contaminated soil may be recovered during drilling operations associated with characterization of the waste site or emplacement of the wellfield network. The major contaminant present at the site is chromium. Any excess recovered soil will be stored in 55-gal waste drums until analytical activities have been completed. It is anticipated, however, that most or all of the soil will be utilized for treatability tests or characterization activities and will ultimately be disposed of as laboratory waste by the organizations performing these activities.

The most significant waste generated during the demonstration will probably be expended caustic solution from the gas treatment system scrubber. It is anticipated that no more than one 55-gal drum of this waste will be accumulated per week. The scrubber solution will consist of one molar sodium hydroxide that will be utilized to remove excess hydrogen sulfide recovered from the extraction boreholes. Acid gases (e.g., hydrogen sulfide and carbon dioxide) will dissolve in the caustic solution, gradually lowering the pH from an initial value of approximately 14 . When the $\mathrm{pH}$ of the scrubber solution drops to a $\mathrm{pH}$ of 10 , the caustic solution in the scrubber reservoir will be replaced and the waste solution placed in a drum. The procedure associated with scrubber solution changeout will be provided in the system operation manua1.

Wastewater will also be collected from the water knockout tank during operation of the gas treatment system. Expended caustic solution and water from the knockout tank will be disposed of by WHC as normal RCRA wastes.

\subsection{SITE CLOSURE}

Following the conclusion of the field demonstration, well casings will be pulled and the boreholes will be infilled or collapsed. All equipment will also cleaned and removed from the site. No radioactive contamination has been identified at the site. Radiation surveys will be performed, however, before the system and associated equipment is released. It is also likely that residues of caustic solution will be present on the gas treatment system. The 
WHC-SD-EN-TP-055, Rev. 0

system will be washed down with soapy water solutions to remove this residue and the skid collection pan will be rinsed and drained. Waste generated during this step will be collected in a 55-gal hazardous waste drum and disposed of as normal RCRA waste.

A post-demonstration inspection will be performed to verify that environmental changes have not occurred that are detrimental to either human or animal safety. It is anticipated that site surface soil will not be exposed to significant concentrations of hydrogen sulfide since the zone targeted for treatment is at a depth of 25 to 35 feet.

\subsection{DESCRIPTION OF PROJECT TASKS}

The following Work Elements and assocated activities have been identified in FY 1996 Technical Task Plan (TTP) \#RL46PL4l prepared by WHC and submitted to the Plume Focus Area (PFA) program within the DOE Office of Technology Development. A related TTP has also been prepared by SNL that is related to demonstration coordination activities. The schedule associated with these activities is presented in Section 9.0.

\subsection{NORK ELEMENT A: PROJECT MANAGEMENT}

General project management activities are specified in TTP \#RL46PL41. This includes production of monthly PTS reports, input to weekly status reports, and management of funds in performance of work scope. Significant technical activities will be summarized in a format appropriate for presentation to DOE.

\subsection{WORK ELEMENT B: GAS TREATMENT SYSTEM DESIGN AND FABRICATION}

The goal of this work element is to build an operational prototype treatment system. Bench and larger scale laboratory testing activities required to optimize treatment parameters and predict system performance will be conducted to support this objective. These activities are primarily the responsibility of the WHC Principal Investigator.

Bench scale testing activities will be conducted for the purpose of acquiring additional information regarding the effect of variation in selected treatment parameters on treatment progress. An important objective of these tests will be to identify the lowest mass ratio of treatment gas to soil that can efficiently reduce chromium at the demonstration waste site. These tests shall also establish purge times required to remove residual hydrogen sulfide from the treated soil. Characterization of treatment products will be performed to determine if treatment efficiencies are affected by the chromate phases present in the waste site soils. Prioritization of testing objectives will be undertaken in consultation with PFA staff and the SNL Technology Demonstration Coordinator. Specific laboratory testing activities to be undertaken in support of the demonstration are provided in Section 3.3. 
WHC-SD-EN-TP-055, Rev. 0

An additional task of this work element will be to define the regulatory treatment objectives that this technology can meet (e.g., TCLP and hazardous waste identification criteria and RCRA Subpart S soil standards). Treatment gases that are less toxic than hydrogen sulfide will also be investigated in testing activities in an effort to develop alternative gas treatment approaches that may be more readily accepted by the regulatory community and the public. These activities will involve interfacing with appropriate regulatory staff, as discussed in Work Element $C$.

Engineering design and fabrication of a prototype gas treatment system was performed in FY 1994 and 1995. A functionality test was successfully completed at the end of FY 1995 (Larkin 1995). Several additional laboratory and field tests will be conducted with the prototype treatment system as a means of assessing and optimizing system performance prior to transporting the system to the demonstration test site. In particular, a test will be performed where a diluted hydrogen sulfide mixture is generated by the system and directed through the gas scrubber. A two-borehole tracer test is also planned for a clean site at Hanford. System procedures will be prepared in conjunction with final development and testing of the gas treatment system.

Modeling of gas flow through the demonstration site soil will also be conducted as a means of assessing treatment system power requirements, flow rates, and the time required to achieve treatment goals, and to assess the best design for the subsurface flow cell that will minimize fugitive releases of treatment gas from the site.

\subsection{WORK ELEMENT C: PERMIT APPLICATIONS AND REGULATORY COMPLIANCE}

This work element addresses reguiatory compliance requirements associated with conducting the field demonstration. Tasks associated with this work element include definition of the size of the treatment zone, duration of the treatment process, determination of performance goals, specification of the process controls needed to manage the demonstration, preparation of a waste analysis plan, preparation of a sampling and analysis plan, and preparation of a closure plan describing system disassembly and restoration of the site. In addition, health and safety issues will be evaluated and potential accident scenarios will be described and mitigating measures identified. The above tasks have been addressed in various sections of this test plan. Successful completion of these activities is primarily the responsibility of the SNL Technology Demonstration Coordinator. The WHC Principal Investigator will support this effort by providing technical input, as necessary.

\subsection{WORK ELEMENT D: SITE PREPARATION AND FIELD DEMONSTRATION}

The various activities identified in this work element are performed by the Technology Demonstration Coordinator (TDC) and/or the Principal Investigator (PI). This activity began with the identification of the demonstration site at WSMR after a review of RFI information. Several Geoprobe ${ }^{\text {TM }}$ or auger holes will be completed and soil samples collected early in the project by the TDC for use in characterization and testing activities (TDC/PI). 
A phased approach with decision points will be employed to ensure safe operations during the demonstration. The first phase will involve drilling the central injection borehole at the site and performing a vacuum step test to obtain gas flow characterization data (TDC). Site characterization information and modeling results will be utilized to support the design and installation of the wellfield network (TOC/PI). The WHC surface gas blending and control system will then be transported to the site after completion of system developmental tests (PI).

During the second phase, full field tracer tests will be conducted using the surface gas treatment system and the subsurface wellfield network (TDC/PI). These tests will be utilized to evaluate the efficiency of the gas sweep over the network and allow adjustment of system parameters to achieve desired flow rates and uniform gas movement through the site. Surface monitoring will be also performed during the tracer tests to ensure that gas emissions do not escape to the surface from the subsurface flow cell. Safety control systems will be evaluated throughout phase 2 activities, including testing of system safety interlocks, and personnel and perimeter monitoring devices.

A demonstration of soil treatment will be conducted in the third phase by injection of the treatment gas mixture (PI). Breakthrough monitoring of hydrogen sulfide will be utilized to assess treatment progress. Hydrogen sulfide residuals will be evacuated from the site after treatment is judged to be complete ( $<10 \mathrm{ppm}$ in extraction gas stream).

After completion of soil treatment, phase 4 will be undertaken by the TDC. Well casings will be removed or sealed, additional post-test borings will be completed to assess treatment efficiency, and all equipment will be disassembled for storage or disposal. A11 results and recommendations will be incorporated into a final report (PI/TDC).

\subsection{ORGANIZATION AND PERSONNEL RESPONSIBILITIES}

WHC will be responsible for installation and operation of the gas treatment system during the demonstration. Staff will be provided by WHC for this purpose. SNL and WSMR staff will ensure that site requirements are met and will participate in demonstration planning, implementation, and evaluation activities. The following sections contain a description of responsibilities for key personnel associated with the field demonstration.

\subsection{SITE MANAGER}

The WSMR environmental restoration manager (Site Manager) is responsible for defining site and regulatory requirements associated with conducting the demonstration and for providing access to site services necessary for supporting field activities. 
WHC-SD-EN-TP-055, Rev. 0

\subsection{PRINCIPAL INVESTIGATOR}

The WHC Principal Investigator is responsible for providing technical direction in developmental and field activities associated with the demonstration, including the following:

- Managing cost and schedule of technology development activities

- Ensuring that the objectives of the demonstration are met

- Conducting the demonstration per the requirements of the Technology Demonstration Coordinator and Site Manager

- $\quad$ Setting up the gas treatment system at the field site

- Operating the system during the demonstration

- Preparing a performance evaluation report that reviews the results of the demonstration relative to each objective.

\subsection{TECHNOLOGY DEMONSTRATION COORDINATOR}

The SNL Technology Demonstration Coordinator is responsible for overall management of field demonstration activities. These activities include preparation of permitting documentation, performance of site characterization activities, installation of the wellfield network, and completion of post-test site restoration activities.

All onsite personnel will report through a Field Team Lead appointed by the Technology Demonstrator Coordinator to accomplish their tasks. The Field Team Lead will ensure that project documentation required for undertaking field activities is complete (e.g., sampling and analysis plan, waste management plan, etc.).

A Health and Safety Project Lead appointed by the Technology Demonstration Coordinator will be responsible for preparation of a Site-Specific Health and Safety Plan. The Health and Safety Project Lead will perform routine visits to the site to ensure compliance with the plan and advise the Site Manager, Technology Demonstration Coordinator, and Principal Investigator of conditions requiring correction. The Health and Safety Project Lead will conduct periodic reviews to ensure that $\mathrm{H}_{2} \mathrm{~S}$ site monitors are functioning properly.

\subsection{SITE SERVICES REQUIREMENTS}

The total connected electrical requirements of the system is approximately $60 \mathrm{hp}$ startup/20 hp operational load of three phase power. The voltage can be either 240 or 480 volts for injection/extraction operations and 120 volts for system instrumentation. A backup generator will be available in the event of a site power failure. 
A tent will be placed over the gas treatment system to prevent rainfall from accumulating in the fluid collection pan.

\subsection{DEMONSTRATION SCHEDULE}

A schedule of the major tasks described in Section 6 is given below:

- Technology Demonstration Test Plan issued

$2 / 29 / 96$

- Site characterization samples collected

$2 / 29 / 96$

- Laboratory treatability testing completed

$3 / 31 / 96$

- Scrubber performance evaluation completed

$4 / 15 / 96$

- Two-borehole tracer test completed (clean site)

$5 / 01 / 96$

- Injection borehole completed at demo site and vacuum step test performed

$5 / 15 / 96$

- Wellfield network installed

$6 / 30 / 96$

- Surface system installed and wellfield tracer test completed

$8 / 31 / 96$

- Permitting documentation completed for $\mathrm{H}_{2} \mathrm{~S}$ injection

$12 / 31 / 96$

- Gas treatment of site soil initiated

$5 / 01 / 97$

- Post-treatment characterization completed

$7 / 31 / 97$

- Site closure activities completed

$9 / 30 / 97$

- Performance Evaluation Report completed

$9 / 30 / 97$

\subsection{REFERENCES}

Cullinane, M.J., and L. Jones, 1989, Solidification and Stabilization of Hazardous Wastes, Hazardous Materials Control March/April.

EPA, 1989, Technology Evaluation Report: SITE Program Demonstration Test, Terra Vac In Situ Vacuum Extraction System, Groveland, Massachusetts, EPA/540/5-89/003a, U.S. Environmental Protection Agency, Risk Reduction Engineering Laboratory, Cincinnati, Ohio. 
EPA, 1992, Test Methods for Evaluating Solid Waste - Physical/Chemical

Methods, U.S. Environmental Protection Agency, Washington, D.C.

Johnson, P.C., C.C. Stanley, M.W. Kemblowski, D.L. Byers, and J.D. Colthart, 1990, A Practical Approach to the Design, Operation, and Monitoring of In Situ Soil-Venting Systems, Ground Water Monitoring Review, v. 10, p. 159-178.

Joss, C.J., and A.L. Baehr, in press, AIR3D - An Adaptation of the Ground Water Flow Code MODFLOW to Simulate Three Dimensional Air Flow in the Unsaturated Zone, Draft U.S. Geological Survey Open-File Report.

Larkin, K.A., 1995, ATP for the Prototype Gas Treatment System, WHC-SD-TD-ATP-002, Westinghouse Hanford Company, Richland, Washington.

Marley, M.C., S.D. Richter, B.L. Cliff, and P.E. Nangeroni, 1989, Design of Soil Vapor Extraction Systems - A Scientific Approach, Presented at the Soil Vapor Extraction Technology Workshop, June 28-29, U.S. Environmental Protection Agency, Risk Reduction Engineering Laboratory, Edison, New Jersey.

McDonald, M.G., and A.W. Harbaugh, 1988, A Modular Three-Dimensional FiniteDifference Ground-Water Flow Model, U.S. Geological Survey Techniques of Water-Resources Investigations, Chap. A1, Book 6, 586 p.

01 schewski, A., U. Fischer, M. Hofer, and R. Schul in, 1995, Sulfur Hexafluoride as a Gas Tracer in Soil Venting Operations, Env. Sci. Tech., 29, p. 264-266.

Pedersen, T.A., and J.T. Curtis, 1991, Soil Vapor Extraction Technology Reference Handbook, EPA/540/2-91/003, U.S. Environmental Protection Agency, Risk Reduction Engineering Laboratory, Cincinnati, Ohio.

Phelan, J.M., 1994, Air Permeability Profiling of a Deep Vadose Zone, Proceedings of the 33rd Hanford Symposium on Health and the Environment, Pasco, Washington, p. 1155-1177.

Pollock, D.W., 1989, Documentation of Computer Programs to Compute and Display Pathlines Using Results from the U.S. Geological Survey Modular ThreeDimensional Finite-Difference Ground-Water Flow Model, U.S. Geological Survey, Open File Report 89-381.

Rohay, V.J., 1993, Tracer Gas Diffusion Test P7an, WHC-SD-EN-TP-035, Westinghouse Hanford Company, Richland, Washington.

Thornton, E.C., and D.E. Trader, 1993, Laboratory Evaluation of the In Situ Chemical Treatment Approach to Soil and Groundwater Remediation, ER'93 Environmental Remediation Conference Proceedings, Augusta, Georgia, p. $159-160$.

Thornton, E.C., M.A. Baechler, M.A. Beck, and J.E. Amonette, 1994, Laboratory Evaluation of the Hydrogen Sulfide Gas Treatment Approach for Remediation of Chromate, Uranium(VI), and Nitrate-Contaminated Soils, WHC-EP-0694, Westinghouse Hanford Company, Richland, Washington. 
Thornton, E.C., and'R.L. Jackson, 1994, Laboratory and Field Evaluation of the Gas Treatment Approach for In Situ Remediation of ChromateContaminated Soils, Proceedings of the 33rd Hanford Symposium on Health and the Environment, Pasco, Washington, p. 949-963.

Thornton, E.C., and R.D. Miller, 1995, Technology Transition to Demonstration Plan - In Situ Remediation of Soil by the Gas Treatment Approach, WHC-SD-EN-TP-051, Westinghouse Hanford Company, Richland, Washington.

Udwari, J.J., and D.W. Chartrand, 1992, Vapor Extraction of VoCs from Fractured Rock, Proceedings of the 1992 U.S. EPA/A\&WMA International Symposium, In Situ Treatment of Contaminated Soil and Water, Air \& Waste Management Association, Pittsburgh, PA, p. 219-230.

WHC, 1990, Geotechnical Engineering Procedure Manual, WHC-IP-0635, Westinghouse Hanford Company, Richland, Washington.

WHC, 1991, Environmental Investigations and Site Characterization Manual, WHC-CM-7-7, West inghouse Hanford Company, Richland, Washington.

WHC, 1993, Gas Treatment and Column Leach Testing of Chromate, Uranium(VI), and Nitrate-Contaminated Soi7, WHC-SD-EN-TP-019, Testplan prepared by E.C. Thornton, C.H. Delegard, M.A. Baechler, and M.A. Beck, Westinghouse Hanford Company, Richland, Washington. 
WHC-SD-EN-TP-055, Rev. 0

\section{DISTRIBUTION}

\section{Number of Copies}

OFFSITE

1

1

2

1

1

2
U.S. Department of Energy

Albuquerque Operations office

P.0. Box 5400

A1buquerque, NM 87115

D.G. Krivitzky

U.S. Department of Energy Savannah River Operations office

P.0. Box A

Aiken, SC 29802

J.A. Wright

Batte 1le Pantex

P.0. Box 30020

Amari110, Texas 79177

W.J. Rogers

K. Van Brunt

EG\&G Idaho, Inc.

Idaho National Engineering Laboratory

P.0. Box 1625

Idaho Falls, ID 83415-3921

L. Cahn

Foster wheeler Environmental Corporation 1981 Snyder Road, Suite 3

Richland, WA 99352

R. Cameron

Sandia National Laboratories

P.0. Box 5800

Albuquerque, NM 87185

D.C. Marozas

J.M. Phelan 
WHC-SD-EN-TP-055, Rev. 0

Number of Copies

3

\section{ONSITE}

4

3

32
White Sands Missle Range

STEWS-DES-E

Building T-150

White Sands Missle Range, NM 88002

H. Magallanes (3)

Bechtel Hanford, Inc.

P.0. Box 969

Richland, WA 99352

M.H. Hyman

H4-80

J.R. James

HO-17

V.M. Johnson

H9-03

K.J. Koegler

HO-18

DOE-Richland Operations

R.F. Christensen

K8-50

J.P. Hanson

K8-50

L.S. Mamiya

K8-50

Westinghouse Hanford Company

M.A. Baechler

S3-90

J.D. Berger

H6-34

G.T. Berlin

H6-34

L.C. Brown

L5-62

J.A. Coates

A.J. Diliberto

H6-06

H6-10

M.J. Duchsherer

L6-33

S.D. Evelo

D.G. Horton

H6-06

J.A. Hunter

R.D. Miller (5)

H6-06

L5-31

H6-32

S.J. Phillips

T.C. Stone

L4-98

E.C. Thornton (12)

B1-10

Central Files (1)

H6-06

OSTI (2)

A3-88

G3-11 
WHC-SD-EN-TP-055, Rev. 0

Number of Copies

3

Pacific Northwest National Laboratory

J.E. Amonette

K9-77

J.S. Fruchter

K6-96

M.E. Peterson

K2-47

Dist-3 